IZA DP No. 10102

Workplace Disability:

Whose Wellbeing Does It Affect?

Getinet A. Haile

July 2016 


\title{
Workplace Disability: Whose Wellbeing Does It Affect?
}

\author{
Getinet A. Haile \\ Nottingham University \\ and IZA
}
Discussion Paper No. 10102
July 2016

\author{
IZA \\ P.O. Box 7240 \\ 53072 Bonn \\ Germany \\ Phone: +49-228-3894-0 \\ Fax: +49-228-3894-180 \\ E-mail: iza@iza.org
}

Any opinions expressed here are those of the author(s) and not those of IZA. Research published in this series may include views on policy, but the institute itself takes no institutional policy positions. The IZA research network is committed to the IZA Guiding Principles of Research Integrity.

The Institute for the Study of Labor (IZA) in Bonn is a local and virtual international research center and a place of communication between science, politics and business. IZA is an independent nonprofit organization supported by Deutsche Post Foundation. The center is associated with the University of Bonn and offers a stimulating research environment through its international network, workshops and conferences, data service, project support, research visits and doctoral program. IZA engages in (i) original and internationally competitive research in all fields of labor economics, (ii) development of policy concepts, and (iii) dissemination of research results and concepts to the interested public.

IZA Discussion Papers often represent preliminary work and are circulated to encourage discussion. Citation of such a paper should account for its provisional character. A revised version may be available directly from the author. 
IZA Discussion Paper No. 10102

July 2016

\section{ABSTRACT \\ Workplace Disability: Whose Wellbeing Does It Affect?*}

The paper examines the link between workplace disability (WD) and job satisfaction (JS) in Britain using linked data from WESR2011. The results obtained indicate workplaces with respondents with disabilities report lower JS vis-à-vis workplaces without such respondents in the private sector. Within private sector workplaces with mixed respondents, the JS of respondents without disabilities declines with the percentage of respondents with disabilities. Also, workplace disability policies and practices are positively (negatively) associated with the JS of respondents with (without) disabilities in the sector. The sector may have to re-examine its dealings with issues of workplace disability.

JEL Classification: J14, J82, J7, I31

Keywords: workplace disability, job satisfaction, linked data, Britain

Corresponding author:

Getinet Astatike Haile

Division of Industrial Economics

Nottingham University Business School

South Building, Jubilee Campus

Wollaton Road

Nottingham, NG8 1BB

United Kingdom

E-mail: getinet.haile@nottingham.ac.uk

\footnotetext{
${ }^{\star}$ The usual disclaimer applies.
} 
"...across the life span (and environmental conditions) everyone experiences limitations and impairments - those who do not currently have disabilities may be referred to as 'temporarily able-bodied..." (Schur et al. 2013, p. 12)

"...disability affects us all - as disabled people ourselves, and as the carers, family, friends, employers, colleagues, and educators of disabled people - and it is the task of all of us to remove the barriers that prevent some from participating fully, and equally, in society" (HLSC, 2016; p. 5)

\section{Introduction}

There are two important policy drives in Britain that make research into issues of workplace disability vital. First, rising life expectancy and the pressure this puts on public finances have led to the drive for extending the working age beyond the State pension age. The prevalence of disability rises with age; and thus this policy initiative is likely to increase the incidence of workplace disability. ${ }^{1}$ Secondly, tightening budgetary conditions have led to measures aimed at encouraging people with disabilities to move away from disability benefits and into employment. This policy initiative too is likely to increase the degree of workplace disability. One wonders, if such policy drives and the statutes aimed at promoting the employment of people with disabilities may benefit from more research into the implications of workplace disability (WD) on employment outcomes. This paper attempts to examine empirically if there is a link between the level of workplace job satisfaction (JS) and the degree of WD in Britain.

Job satisfaction forms an integral part of subjective well-being fitting within the broader notion of mental health and with a link to individual well-being (Argyle 1989; Warr 1994, 1999; Sousa-Poza and Sousa-Poza 2000; Rode 2004; Kahneman \& Krueger 2006). Traditionally, it has been regarded as an important predictor of labour market behaviour such as quits and absenteeism (Hamermesh 2001; Clark et al. 1998; Akerlof et al. 1988; Levy-Garboua et al. 2007) job performance and productivity (Iaffaldano \& Muchinsky 1985), organisational performance (Ostroff 1992) and innovation (Shipton, et al. 2006), among others. In the UK, even though workplace accidents and musculo-skeletal disorders have been declining generally, reported

\footnotetext{
${ }^{1}$ The prevalence of disability among adults over the State Pension age stands at $45 \%$ compared with that for working age adults, which is $16 \%$ (DWP 2014).
} 
stress and mental health problems continue to escalate (Vickerstaff et al., 2012; HSE, 2009). There has also been renewed interest in the measurement and analysis of subjective wellbeing outcomes in public policy discourses in Britain and elsewhere (Dolan et al. 2011; Oswald 2010; Stiglitz et al. 2009; Black 2008).

Research into the link between JS and WD in Britain can be informative for employers and policy makers alike for a number of reasons. First, Britain is reported to have one of the largest numbers of people with disabilities vis-à-vis other OECD countries, with the size of disability benefit claimants tripling from its level in the 1970s and proportionately fewer claimants being in employment due to employment disadvantage for people with disabilities (Jones 2016; Baumberg et al. 2015; Blekesaune 2007; EHRC 2008). Secondly, although there has been some progress since the introduction of statutes aimed at addressing discrimination against people with disabilities, there is evidence of discrimination on the basis of health and disability (Jones 2008, 2006; EHRC 2008, Berthoud and Blekesaune 2007, Madden 2004, Jones et al. 2003). ${ }^{2}$ The 2016 HLSC report on whether the Equality Act 2010 adequately supports the fight against disability discrimination concluded that much more needs to be done in this respect (HLSC, 2016). This evidence may mean that people with disabilities experience a reduction in their JS due to co-worker and employer discrimination. Equally, co-workers without disabilities may experience a reduction in their JS if, for example, they perceive employees with disabilities or the workplaces hiring them somehow affect them adversely, or they have a taste for discrimination against co-workers with disabilities. ${ }^{3}$ Third, although there has been a growing interest in recent years, there is a dearth of evidence relating to the link between WD and workplace JS. Crucially, the existing evidence linking JS and WD is not clear-cut, with some conflicting findings. For example, Pegan and Malo (2008) and Uppal (2005) find workers with disabilities reporting higher levels of job satisfaction while Jones et al. (2014) and Perales and Tomaszewski (forthcoming) find the opposite result.

This paper aims to gain some new insights into whether WD adversely affects JS; and, if so, to explore whether the adverse link may be due to the nature of workplaces, co-workers' prejudice or some combination of these. It uses data form

\footnotetext{
${ }^{2}$ The main statutes include the 1995 Disability Discrimination Act and The Equality Act 2010.

${ }^{3}$ For example, co-workers may perceive the 'reasonable adjustment' provision, which the 1995 DDA instituted to accommodate the needs of people with disabilities and which includes flexible working, adversely affects them.
} 
WERS2011 and deploys alternative empirical approaches that allow firmly establishing the JS-WD link. The results obtained reveal that: $(i)$ workplaces with respondents with disabilities report significantly lower JS vis-à-vis workplaces without such respondents, (ii) within workplaces with mixed respondents, workplace JS is found to decline with the percentage of respondents with disabilities, (iii) respondent disability status based sub-group analysis uncovers that the reduction in JS found is exclusive to co-workers without disabilities, (iv) disability-friendly workplace policies and practices increase (reduce) the JS of employees with (without) disabilities. That the adverse link between JS and the percentage of respondents with disabilities found is specific to co-workers without disabilities seems to suggest factors related to intergroup dynamics, including co-worker discrimination, being the reason behind the adverse link. However, all the findings are specific to the private sector. This suggest that workplace related factors, including what Schur et al. (2013; 2005) refer to as 'corporate culture', may be the more credible culprits behind the adverse JS-WD link. It seems, therefore, that the private sector has to devise a strategy that deals with issues of workplace disability more effectively.

The remainder of the paper is organised as follows. Section Two provides theoretical background and the review of related literature. Section Three describes the data and variables used in the empirical analyses conducted. Section Four discusses the empirical approaches deployed. Section Five discusses the results before the final section concludes the paper.

\section{Background and related literature}

The need for more research into WD and employment outcomes in Britain cannot be over emphasized. Various recent estimates put the proportion of working age people with long-standing illness or impairment to be in excess of 30 per cent of the population. Of this, some 17 per cent have a limiting long-term illness, impairment or a disability (HLSC 2016; DWP 2014; Jones and Wass 2013). ${ }^{4}$ Thus, people with disabilities constitute a significant proportion of the labour force in Britain; and this proportion is set to increase given current demographic projections. Regardless of whether disability is viewed as a fluid and continuous notion (i.e. the

\footnotetext{
${ }^{4}$ Compared with other European countries Britain is reported to have larger numbers of people with long-term illnesses, although the figures are comparable to that of the USA (Blekesaune 2007, Stone-Romero, et al., 2006, EHRC 2008).
} 
Universalist view of disability) or as a fixed and dichotomous one, its influence extends beyond those with the condition.

There is considerable variation in the nature of disability conditions among people with disabilities. Notwithstanding such variations, the bulk of the evidence suggests that people with disabilities fare worse in labour market outcomes generally vis-à-vis their counterparts without disabilities. The employment gap is estimated to be in excess of 40 percentage points (Jones and Wass 2013; DWP, 2014). Official figures from the DWP report that people with disabilities are more likely to be in employment now than in the past. Berthoud (2011), on the other hand, reports that the 'disability employment penalty' has increased from $17 \%$ in 1987 to $28 \%$ in $2000 .^{5}$ Importantly, fewer than 50 (75) percent of the people with (without) disabilities are in employment in Britain. Also, some 50 (15) percent of the people with (without) disabilities are economically inactive (Smith and Twomey, 2002; Kersley et al., 2006).

The bulk of the evidence on WD and employment outcomes focuses on disparities in terms of wages/earnings and benefits, hours of work, job security/layoff, (re-)employment, promotions, decision making and training, among others. The broad consensus is that employees with disabilities fare worse in these outcomes vis-à-vis their counterparts without disabilities (Schur et al. 2009; Jones and Latreille 2010; Jones 2008, 2007, 2006; Jones et al. 2003, Baldwin and Schumacher 2002, Madden 2004, Kersley et al., 2006, Berthoud and Blekesaune, 2007, Berthoud 2011, 2008, 2006; Kidd et al. 2000). On the other hand, there is generally a dearth of evidence on the JS-WD link, although there has been a growing interest in research in the area more recently, and the limited existing evidence is not clear-cut with conflicting findings as the review below underscores.

Using data from the Australian HILDA survey Jones et al. (2014) found that work-limiting disability reduced job satisfaction in a causal manner. Jones (2016) used data from WERS2004 to find that employees with disabilities expressed less job satisfaction and commitment towards their organization vis-à-vis their counterparts without disabilities. Using data from WERS2011 and a 'within-job' model, Perales and Tomaszewski (forthcoming) found that workers with disadvantaged statuses

\footnotetext{
${ }^{5}$ Berthoud (2011)'s data are slightly dated; but he attributes the difference between his and DWP's account of the trend in the employability of people with disabilities to the increase in the reported prevalence of disability in the Labour Force Survey, which DWP's report relies on.
} 
generally report higher satisfaction with the same jobs vis-à-vis those with advantaged statuses. However, workers with lasting health conditions were found to have lower job satisfaction vis-à-vis their counterparts without disabilities, a result the authors regarded as "a major exception" to the pattern of their findings. Uppal (2005) used nationally representative Canadian data to find workers with mobility disabilities no longer had lower job satisfaction than their counterparts without disabilities once workplace characteristics were controlled for. However, a negative link between disability and job satisfaction persisted for workers with other types of disabilities even after controlling for workplace characteristics albeit with lower magnitude. Burke (1999) also examined the work and health experiences of women in nine occupational groups in Ontario and found that women with disabilities have lower job satisfaction and other wellbeing indicators vis-à-vis women without disabilities.

Other studies, on the other hand, report an outright positive, a qualified positive or no significant link between JS and WD. Pegan and Malo (2008) used Spanish data from the ECHP to find that workers with disabilities are more likely to report higher levels of job satisfaction, which they attribute to such workers having lower expectations about jobs in the first place vis-à-vis workers without disabilities. Having studied 30,000 employees from fourteen companies in the US monitored over the period 2001-2006, Schur et al. (2009) found that where employees reported higher (lower) levels of company fairness and responsiveness, they found no (higher) significant gap in terms of job satisfaction, company loyalty, willingness to work hard and turnover between employees with and without disabilities. They concluded that corporate cultures, which are responsive to the needs of all employees, are especially beneficial for employees with disabilities.

The review above highlighted two main points. First, there is a general consensus that employees with disabilities fare worse in terms of most employment outcomes due to stereotypes and associated stigmas from employers, co-workers and clients despite some evidence suggesting that workers with disabilities "have lower turnover and absenteeism rates, and perform as well, if not better, than people without disability" (Stone-Romero, et al. 2006, p. 402). Secondly, there is a lack of consensus regarding the JS-WD link. Evidently, the reviewed studies cover different settings, use different datasets and methodologies. There is also considerable heterogeneity in the conditions of disability, not to mention the 'thorny issue' of measuring them. Nonetheless, the conflicting evidence concerning the JS-WD link warrants further 
research in order to offer less ambiguous evidence to employers and policy makers alike.

\section{Data}

3.1 Overview of the data and the study sample

The data come from the 2011 British Workplace Employment Relations Surveys (WERS2011). The WERS2011 constitute the most recent and authoritative source of information on employment relations in Britain covering a whole host of topics relating to both employers and employees. The surveys solicited responses from managers and employees through: $(i)$ management questionnaire, which was administered in a face-to-face interview with managers in charge of the day-to-day task of employment relations and (ii) employee questionnaire, which was selfcompleted by up to 25 employees in participating workplaces. WERS2011 offer linked employer-employee data representative of all workplaces with five or more employees in Britain (van Wanrooy et al. 2013).

The 2011 survey monitored 2680 establishments in total. Of these, 1923 establishments took part in the employee surveys, constituting the initial sample for the analysis conducted in this paper. The elimination of missing values on relevant workplace and employee characteristics led to the retention of a final sample of 1769 workplaces, which makes up $92 \%$ of the initial sample of workplaces. Of the retained final sample of workplaces, 984 workplaces had at least one respondent with a selfreported disability (see details on the wording of the disability question in the next sub-section), while the remaining 785 workplaces had none. Of those workplaces with at least one respondent with a disability, 970 workplaces had a mix of respondents with and without disabilities, while 14 workplaces had all their respondents reporting to have disabilities. As detailed in Section 4, the analysis examining the JS differentials between workplaces with and without respondents with disabilities uses all 1769 workplaces in the final sample, thus covering $92.2 \%$ of the workplaces with responding employees. On the other hand, the analyses investigating the within workplace JS-WD dynamics, which necessitate a mix of respondents with and without disabilities, relies only on the 970 workplaces that had the two types of respondents thus relying on $50.4 \%$ of the workplaces with responding employees. 


\subsection{Definition of variables}

\subsubsection{Outcome (JS) and key control (WD) measures}

The WERS2011 survey solicited employees' response on nine different facets of JS as well as whether they had a health problem or a disability. Employees' responses to these questions have been used to generate workplace-level JS outcome and disability status measures as follows. The WERS2011 survey asked employees to rate - on a five-point scale from 'very satisfied' to 'very dissatisfied' - "how satisfied are you with the following aspects of your job": ( $i$ ) the sense of achievement they get from their work; (ii) the scope for using their own initiative; (iii) the amount of influence they have over their job; (iv) the training they receive; (v) the opportunity to develop their skills, (vi) the amount of pay they receive; (vii) their job security; (viii) the work itself and (ix) their involvement in decision making. Self-reported levels of satisfaction on each of the facets with 5-point scores have been reverse coded so that their respective values increase with the level of reported satisfaction, where ' 1 ' is "very dissatisfied" and ' 5 ' is "very satisfied". These reverse coded responses were used to yield three different workplace JS outcomes.

First, the responses to each of the domains $(k)$ are averaged over the total number of respondents $(i)$ in each retained workplace $(j)$ to yield 'workplace average domain-specific $\quad J S^{\prime} \quad-\quad$ i.e. $\quad \bar{y}_{j k}=\sum_{i=1}^{N} \frac{y_{i j k}}{N}$, where $1 \leq i \leq 25 ; j=1, \ldots, 1769, \& k=1, \ldots, 9$.

Summing across these average domain-specific JS outcomes - i.e., $y_{j}=\bar{y}_{j}=\sum_{k=1}^{9} \bar{y}_{j k}-$ yielded the first outcome measure - 'workplace average overall JS' which ranges between 13 and 45 for the final sample of workplaces with and without respondents with disabilities. Figure 1 depicts plots of the workplace average overall JS disaggregated by the qualitative WD measure, while Tables A1 and A2 in the Appendix provide summary statistics on these outcomes.

Secondly, for workplaces with a mix of respondents with self-reported disabilities $\left(N_{1}\right)$ and without $\left(N_{2}\right)$, thus in this case $N=N_{1}+N_{2}$, a similar averaging was carried out as before; but this time separately over the total number of respondents with and without disabilities in each workplace. This yielded separate 'average domain-specific JS outcomes for respondents with disabilities' \& 'average domain-specific JS outcomes for respondents without disabilities'. That is, 
$\bar{y}_{j k}^{d}=\sum_{i=1}^{N_{d}} \frac{y_{i j k}^{d}}{N_{d}}$, where $1 \leq i<25 ; j=1, \ldots, 970 ; k=1, \ldots, 9$ and $d=1,2 . \quad$ Summing across each of these average domain-specific JS outcomes then yielded the two remaining JS outcome measures - 'workplace average overall JS for respondents with disabilities' and 'workplace average overall JS for respondents without disabilities' - i.e., $y_{j}^{d}=\bar{y}_{j}^{d}=\sum_{k=1}^{9} \bar{y}_{j k}^{d} \cdot 6$

Figure 1: Workplace overall JS, by workplace WD status

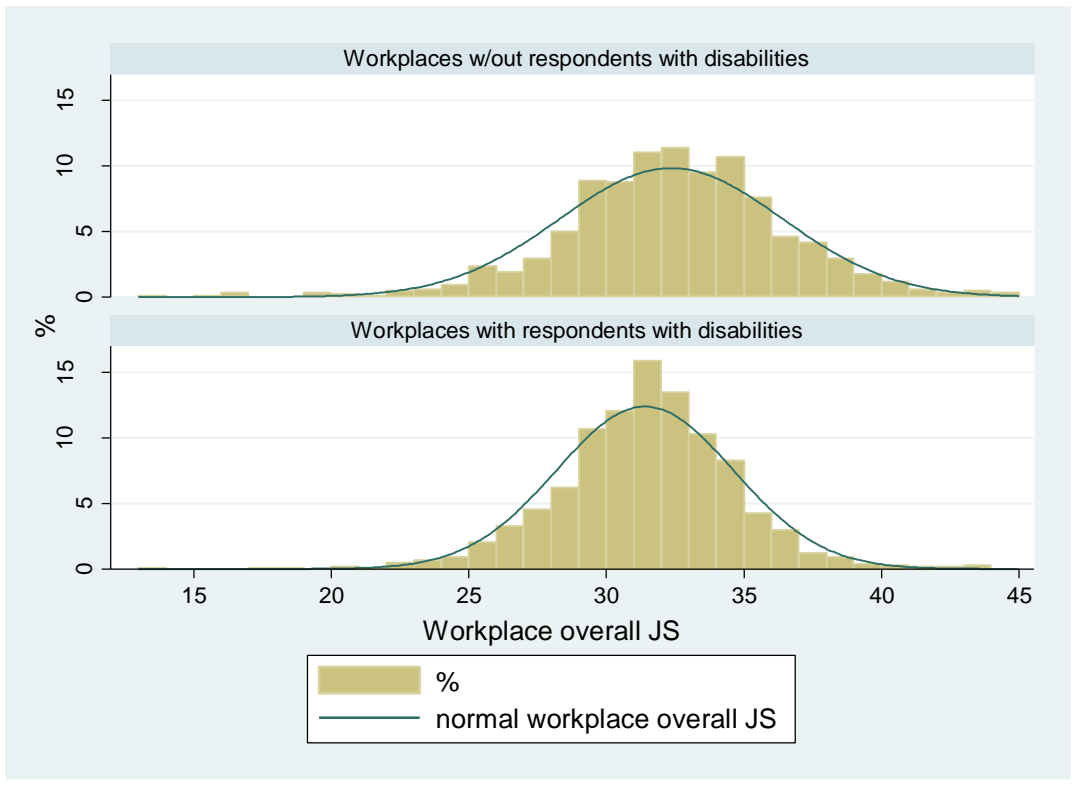

The paper uses two key WD measures as alternative controls, which are both obtained from employees' own responses on whether they had a health problem or disability. The WERS2011 survey question monitoring disability status is the following: "Are your day-to-day activities limited because of a health problem or disability which has lasted, or is expected to last, at least 12 months? Please include problems related to old age", with three possible answers of ' $n o$ ', 'yes, limited a little' and 'yes, limited a lot'. In the original sample of workplaces with responding employees, $89.6 \%, 8.3 \%$ and $1.3 \%$ of the respondents reported 'no', 'yes, limited a little' and 'yes, limited a lot' respectively. If an employee responded 'yes' to the disability question, i.e. regardless of whether the condition limits one's day-to-day

\footnotetext{
${ }^{6}$ Principal Component Analysis (PCA) on the nine facets of JS identified a single factor with an eigen value above 1 (4.72) and a Kaiser-Meyer-Olkin (KMO) sampling adequacy measure of 0.90. This supports the approach of generating a single/overall measure of JS at the level of the individual respondent. The approach adopted in this paper computed workplace average JS measure, however. Perales and Tomaszewski (forthcoming) have used a similar approach.
} 
activities 'a little' or 'a lot', the employee is regarded as having a health problem or a disability in this paper. Also, the paper makes the reasonable assumption that if a health condition is reported to limit one's day-to-day activities, the condition must also limit one's work activities. ${ }^{7}$

The first measure of WD generated is a qualitative measure of WD, which takes a value 1 if at least one employee in a workplace reported to have a disability and 0 otherwise. This dummy measure of WD is used in the investigation of the JS differential between workplaces that have respondents with disabilities and those that do not. The summary statistics in Table A1 shows that $56 \%$ of the retained workplaces in the final sample had at least one respondent self-reporting to have a disability. Secondly, a continuous measure of WD has also been generated for the sub sample of workplaces with a mix of respondents with and without disabilities. This is achieved by computing a $\%$ measure of workplace disability - i.e., $\left[\left(N_{1} / N\right) \times 100\right] .^{8}$ As can be seen from Table A1 in the Appendix, 9.3\% of the respondents in the retained final sample of all workplaces reported to have disabilities. This figure increases to 16.7\% (Appendix Table A1), if only workplaces with at least one respondent with a disability are considered; and $15.5 \%$ (Appendix Table A2) if only workplaces with mixed respondents are considered, i.e. excluding workplaces with all or none of their respondents reporting to have disabilities.

Table 1 reports a summary of the workplace-level average domain-specific and overall JS outcomes computed for all workplaces. The Table also reports differences in these outcomes between workplaces with and without respondents with disabilities as well as between the private and the public sectors. In all cases, there are statistically significant differences in JS between workplaces with and without disabilities, in favour of the latter. Thus, the raw data reveals that workplaces that do not have respondents with disabilities have a higher level of JS on average whether this is viewed in terms of specific domains or in aggregation. With the exception of two of the nine domains, viz. 'the sense of achievement' and 'the work itself', there are also statistically significant differences in the levels of reported JS between the private and the public sector, in favour of the former.

\footnotetext{
${ }^{7}$ Distinguishing between those whose health condition limits their day-to-day activities 'a little' and 'a lot' is not feasible empirically given that only $1.3 \%$ of all respondents in the original sample reported the health condition limits their day-to-day activities ' $a$ lot'. This drops further in the final sample.

${ }^{8} \mathrm{~A} \%$ measure, as opposed to a count measure of respondents with disabilities, is preferable since it is more likely that there would be a respondent with a disability the larger the number of respondents in a workplace (depending on workplace size, there can be up to 25 respondents in some workplaces in WERS).
} 
[Table 1 about here]

Table 2 reports summary statistics on average domain-specific and overall workplace-level JS disaggregated by the disability status of respondents in the subsample of workplaces with a mix of respondents with and without disabilities. The final column reports that there are significant differences in JS between the two groups of respondents, those without disabilities reporting higher levels of JS vis-à-vis co-respondents with disabilities. Looking at sectoral differences within each group of respondents reveals that respondents in the private sector generally report significantly higher levels of JS compared with their counterparts in the public sector (columns 4 and 8).

[Table 2 about here]

Figure 2: Workplace overall JS \& \% respondents with disabilities, all and mixed workplaces
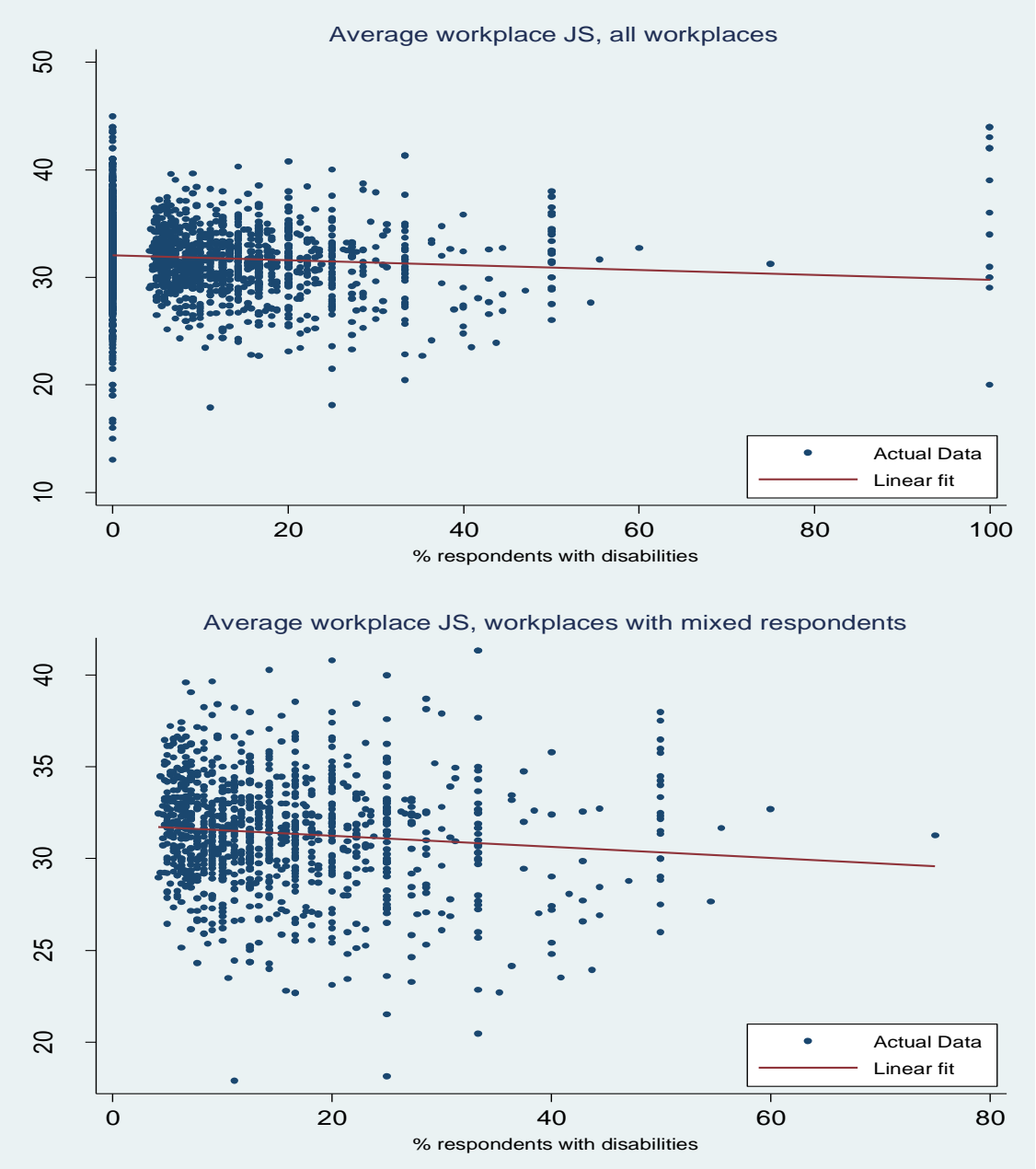
Figure 2 depicts the average workplace JS and the percentage of respondents with disabilities. The top panel shows the JS-WD patterns for the full sample of workplaces, including those with $100 \%$ of the respondents reporting to have disabilities and those that have none. The bottom panel, on the other hand, is specific to those workplaces with mixed respondents only, i.e., those with respondents with and without disabilities. In both cases, the raw data reveals a negative relationship between average workplace JS and the percentage of respondents with disabilities. Although the difference appears to be marginal, the negative relationship is more apparent in the bottom panel.

\subsubsection{Workplace disability policies \& practices and other controls}

Accounting for the type of workplace disability policy and practice is essential in examining the JS-WD link. The workplace disability policy and practice measure used in the empirical analysis is a count measure generated from employers' 'yes'/'no' responses to each of the following seven questions, which relate to whether the workplace: $(i)$ "has formal strategic plan on employee diversity", (ii) "whether the strategic plan explicitly mentions disability", (iii) "monitors promotion to identify indirect discrimination by disability", (iv) "reviews promotions to identify indirect discrimination by disability", (v) "review relative pay to identify indirect discrimination by disability", (vi) "whether employer has special procedure to encourage workers with disabilities" and (vii) "if the workplace has made formal assessment of accessibility of the workplace to those with disabilities".

Table 3 reports summary statistics on the count measure of workplace disability policy and practice together with each of its seven constituent parts. For the full sample, the Table reveals that there is significant difference between workplaces with and without respondents with disabilities in terms of each of the workplace disability policy and practice measure (columns 1 to 4). Accordingly, workplaces with respondents with disabilities score significantly higher in terms of disability 'friendly' policies and practices. The Table also reports significant difference in the policy and practice measures between the private and the public sectors (columns 5 to 7), with the latter scoring higher in these measures. Similarly, the data for the sub-sample of workplaces with and without disabilities reveals statistically significant difference between the private and the public sector (columns 8 to 11), with the public sector 
once again scoring better in terms of each of the policy and practice measures including the count one.

[Table 3 about here]

A number of other workplace-level controls has been used in the empirical analysis conducted, which include workplace age, workplace size, ownership, industry and geographic location. Employers have also provided information on the number of employees they have who are paid 'adult national minimum wage or less'. This has been used to generate a workplace-level measure of the $\%$ of employees on the minimum wage or less. Although it may be crude, this control is thought to provide some measure of the level of job quality. Tables A1 and A2 in the Appendix provide summary statistics on the full range of outcome and control variables used in the analysis undertaken for, respectively, all workplaces in the final sample and for the sub-sample of workplaces with a mix of respondents with and without disabilities.

\section{Study hypotheses and empirical strategy}

\subsection{Study hypotheses}

A priori, employer and/or co-worker centred theoretical explanations can be put forward to explain disparities in JS across and within workplaces. On the former, some workplaces can be less pleasant due to poor pay and conditions (similar to Acemoglu 2001; Layard 2004) and/or inferior 'corporate culture' (Schur et al. 2013,

2009). ${ }^{9}$ One may reasonably assume that people with disabilities sort into less pleasant workplaces, on average, compelled by employer discrimination and other restrictions, experiencing lower JS in such workplaces. If so:

Hypothesis 1: 'less pleasant' workplaces entail a JS penalty vis-à-vis pleasant ones.

\footnotetext{
${ }^{9}$ Acemoglu (2001) and Layard (2004) dwell on jobs - "bad jobs" - in particular, rather than the workplace as used here. Corporate culture is defined as "the explicit and implicit attitudes, norms, policies, and practices in an organization" (Schur et al. 2013, p. 72). Abowd et al. (1999) found that firm effects explain only small proportions of the inter-industry and firm-size wage differential. If so, the type of workplace 'corporate culture' and/or conditions may be more important here.
} 
Within workplaces with mixed respondents, the JS penalty may increase with the group size $(\%)$ of respondents with disabilities. This may be for two main reasons. First, some unscrupulous employers with inferior corporate culture, who may not employing people with disabilities otherwise, may recruit such people driven by cost considerations. If so, the larger the group size of employees with disabilities, the more miserable the workplace might be with a larger reduction in JS. Secondly, there may be identity theory and inter-group competition related explanation (Akerlof and Kranton 2000; Alesina and La Ferrara 2000, 2005). Accordingly, the utility individuals drive from joining a group depends positively (negatively) on the share of their (other) group members. In a workplace setting, where incentives may be linked to team effort and where competition among co-workers may be the rule rather than the exception, group identity based rivalry may create strained interpersonal relations, which may in turn adversely affect employee JS.

Hypothesis 2: within 'less pleasant' workplaces, the JS penalty increases with the group size of co-workers with disabilities.

The question of which group of employees may take the brunt of the JS reduction, if any, may be an empirical matter since the JS-WD dynamics can be hypothesised to go either way. First, co-worker discrimination, stereotypes and associated stigmas can reduce the JS of employees with disabilities. ${ }^{10}$ Co-worker discrimination occurs when people behave as if they refuse to change their stereotypes about the capabilities of discriminated individuals or groups. It is to do with taste and may not change in the face of favourable information about the group, for example regarding the capabilities of people with disabilities (Becker 1971; Arrow 1972, 1973; Phelps 1972). ${ }^{11}$ Equally, insufficient accommodation of employees with disabilities or inferior corporate culture, which are found to be particularly beneficial for employees with disabilities (Schur et al. 2009), can also reduce the JS of employees with disabilities.

\footnotetext{
${ }^{10}$ Employers with a taste for discriminating people with disabilities may not recruit them in the first place, even though one cannot rule out circumstances where cost considerations force some unscrupulous employers to do so. Co-worker discrimination may thus be a valid focus in the within workplace setting considered here.

${ }^{11}$ Other, theories of relevance include information, where (employer) discrimination is the result of asymmetric information regarding (the productivity of) the discriminated individual (Aigner and Cain 1977), language (difference) based discrimination (Lang 1986) and Lazear (1999)'s communication costs explanation of (racial) diversity.
} 
On the contrary, it may be that employees with disabilities have lower expectations of securing jobs to begin with, given the labour market restrictions they face; and perhaps they cherish their jobs better and report a higher JS (Pegan and Malo 2008). Also, the presence of employees with disabilities in workplaces and necessary adjustments thereof might somehow be construed adversely by employees without disabilities, perhaps due to envy and/or a taste for discrimination. If so, this may reduce the JS of co-workers without disabilities particularly if such workers are unable to sort into better workplaces; and given that they cannot blame their misfortune on employer disability discrimination or similar restrictions as their counterparts with disabilities might do. If so, employees without disabilities may report lower JS.

Hypothesis 3: within 'less pleasant' workplaces, the question of which group of employees takes the brunt of the JS reduction can only be settled empirically.

\subsection{Empirical strategy}

The paper deploys three different empirical approaches, each of which uses the overall JS outcome measures described in Section 3. The first approach examines whether there is a JS differential between workplaces with and without respondents with disabilities. The raw data summarised in Section 3 revealed that there is a JS differential in favour of workplaces without respondents with a disability. A multivariate analysis using all 1769 workplaces in the final sample is conducted to examine if the JS-WD differential observed in the raw data remains after controlling for a broad range of workplace characteristics. The model to be estimated has the following form:

$$
y_{j}=\alpha_{j}+d_{j}^{\prime} \theta+\mathbf{x}_{j}^{\prime} \beta+\varepsilon_{j}, \quad j=1, \ldots, J
$$

where $j$ indexes workplaces $(j=1, \ldots, 1769) ; d$ is a dummy measure of WD ( 1 if a workplace has respondents with disabilities); $\mathbf{x}$ stands for the vector of workplace characteristics, which includes the workplace policy and practice measure as well as the broad range of other workplace characteristics discussed in Section 3 , and $\varepsilon_{j}$ is the workplace-level idiosyncratic error term. 
The second empirical approach focuses on the sub-sample of workplaces with a mix of respondents with and without disabilities. This analysis allows examining the within workplace JS-WD pattern depicted in Figure 2 and the raw data described in Section 3. The second model to be estimated is given by:

$$
y_{j}=\alpha_{j}+w d_{j}^{\prime} \delta+\mathbf{x}_{j}^{\prime} \beta+\varepsilon_{j}, \quad j=1, \ldots, J
$$

where, as before, $j$ indexes workplaces $(j=1, \ldots, 970) ; w d$ is the continuous $(\%)$ measure of WD and the other arguments are as in equation (1).

The third approach also focuses on the sub-sample of workplaces with a mix of respondents. However, here the JS outcomes used are those that are disaggregated by the disability status of respondents within each workplace as described in detail in Section 3, i.e. the average workplace overall JS for respondents with disabilities and the average workplace overall JS for respondents without disabilities. These represent outcomes for two different groups of respondents within the same workplaces. As such, they are likely to be correlated due to common observable and unobservable workplace characteristics shared by the two groups. Given this, modelling the two outcomes jointly is appropriate. To this end, the third approach deploys the Seemingly Unrelated Regression (SUR) model (Zellner, 1962), which is specified as follows:

$$
\left\{\begin{array}{l}
y_{j}^{1}=\alpha_{j}^{1}+w d_{j}^{\prime} \delta_{j}^{1}+\mathbf{x}_{j}^{\prime} \beta_{j}^{1}+\varepsilon_{j}^{1} \\
y_{j}^{2}=\alpha_{j}^{2}+w d_{j}^{\prime} \delta_{j}^{2}+\mathbf{x}_{j}^{\prime} \beta_{j}^{2}+\varepsilon_{j}^{2}
\end{array} \quad, j=1, \ldots, J\right.
$$

where, as before, $j$ indexes workplaces $(j=1, \ldots, 970)$; $w d$ represents the continuous measure of WD; $\mathbf{x}$ stands for the vector of workplace characteristics, the superscripts 1 and 2 represent respondents with and without disabilities respectively, and $\varepsilon_{j}^{d}$ with $d=1,2$ are the idiosyncratic error terms each of which is assumed to be conditionally homoscedastic, independent across workplaces and with zero mean. As noted earlier, equation (3) represents JS outcomes for two different groups of respondents within the same workplaces. As a result, it is likely that $E\left(\varepsilon_{j}^{1} \varepsilon_{j}^{2} \mid \mathbf{x}\right)=\sigma^{1,2} \neq 0$. The SUR framework accounts for such correlation between the two equations using the GLS estimator, which also provides Chi-squared statistics 
from the Breusch-Pagan test on the independence of the errors from the jointly estimated equations. ${ }^{12}$ This analysis will inform if hypothesis 3 or hypothesis 4 is the most likely explanation.

\section{Empirical results and discussion}

Table 4 reports results based on the first approach (equation 1) described in the preceding section, with three different specifications for the full sample of workplaces and separately by ownership status. The results reveal a negative link between the workplace overall JS and qualitatively measured WD. The relationship is only marginally significant in the second and third specifications estimated for the full sample; but confirms the raw data pattern. Thus, workplaces with respondents with disabilities generally have a lower average overall JS vis-à-vis workplaces without such respondents. Workplace ownership based sub-group analysis uncovers that the negative link found holds only for the private sector, with no significant link found for the public sector.

Table 5 reports results based on the second empirical approach (equation 2), which is based on workplaces with mixed respondents only and using continuously measured WD. As in the first analysis, three different specifications of the JS equation have been estimated. The results obtained indicate that there is no statistically significant link between average workplace overall JS and the group size (\%) of respondents with disabilities for the combined sample. However, ownership status based sub-group analysis uncovers that for workplaces in the private sector there is strongly significant negative link between average workplace overall JS and WD. In other words, workplace JS generally declines with the percentage of respondents with disabilities in the private sector. What is more, the sub-group analysis also reveals that for workplaces in the private sector there is a significant negative relationship between overall JS and the workplace disability policy and practice measure used. These results seem to suggest therefore that in the private sector, workplace overall JS declines: $(i)$ as the percentage of respondents with disabilities increases and (ii) with the number of disability friendly workplace policy and practice measures in place.

\footnotetext{
${ }^{12}$ This also provides some efficiency gain from combining the two equations of interest. Another advantage of the SUR model is that it permits conducting joint test(s) of significance on the coefficients of interest from the two equations straightforwardly. Tests on the joint significance of the WD and the disability equality measure have been carried out; and results, not reported here, reject the null that the WD and the disability equality coefficients are zero in the two equations estimated.
} 
Table 6 reports results from the SUR model (equation 3), controlling for the full set of workplace characteristics that includes the workplace policy and practice measure. $^{13}$ In all cases, the Breusch-Pagan test of independence rejects the null hypothesis of 'no contemporaneous correlation' lending support for estimating the JS equations for the two groups of employees jointly. The results for the full sample of workplaces with mixed respondents (columns $1 \& 2$ ) show that there is no significant link between JS and WD for either group of respondents. Thus, in line with the results reported in Table 5 (column 3), no distinction can be made between respondents with and without disabilities for the combined sample. However, workplace ownership status based sub-group analysis uncovers a divergent JS-WD link between respondents with and without disabilities in private sector workplaces (columns $3 \&$ 4). Specifically, there is a significant negative link between JS and the group size (\%) of respondents with disabilities for respondents without disabilities. Thus, the private sector specific negative link between JS and WD that the second analysis revealed is peculiar to respondents without disabilities.

The estimated coefficients on the count measure of workplace disability policies and practices are also found to be instructive. Specifically, disability friendly workplace policies and practices are found to increase the JS of respondents with disabilities in the combined sample of private and public sector workplaces. Subgroup analysis uncovers contrasting results for respondents with and without disabilities in private and public sector workplaces. In particular, disability friendly workplace policies and practices are linked with a reduction of the JS of respondents without disabilities in the private sector. On the other hand, these policies and practices are linked with an increase in the JS of respondents with disabilities in the public sector. The discrepancy between private and public sector workplaces in terms of their scores on the workplace disability policies and practices measures is something that the raw data summarised in Table 3 (columns 9 to 11) highlighted. What the SUR based analysis has uncovered additionally is the divergence between respondents with and without disabilities in private and public sector workplaces.

Aside from the link between JS and the key controls of WD and workplace policies and practices, the empirical analyses conducted controlled for a number of other workplace characteristics as pointed earlier. Some of the results that run across

\footnotetext{
${ }^{13}$ SUR estimation results with no workplace control and excluding the workplace policy and practice control are provided in Appendix Tables A3 and A4 respectively.
} 
the analyses conducted include the following. Workplaces in the private sector are found to have a significant JS advantage over their counterparts in the public sector generally as the three empirical analyses have revealed, which the raw data described in Section 3 have also highlighted. No significant link is found between the job quality measure used (\% of employees on minimum wage) and JS in the first two analyses conducted. However, the SUR based analysis reveals some significant positive link between the size (\%) of employees on the minimum wage and JS for the combined sample of workplaces. Ownership based sub-group analysis reveals that the positive link found is specific to respondents with disabilities in the private sector. Another result that only emerges in the SUR based analysis is the link between workplace age and JS, which suggests a negative link between JS and workplace age for respondents with disabilities in the combined sample. Sub-group analysis reveals that the JS-workplace age link found for respondents with disabilities is barely significant for the public sector, thus the link being more relevant for respondents with disabilities in the private sector. Compared with small sized workplaces (5 to 9 employees), larger workplaces have significantly lower JS as the analysis on the full sample reveals. A different picture emerges from the analysis using workplaces with mixed respondents however. In particular, the JS-workplace size link found is specific to the private sector for the most part, as the second analysis revealed, and for respondents without disabilities in particular, as the results from SUR reveal. The relationships between the industrial and regional background of workplaces, on the one hand, and JS, on the other, are varied in nature to yield a systematic narration.

\section{Summary and Conclusion}

The paper examined the link between workplace job satisfaction (JS) and workplace disability (WD). It highlighted that job satisfaction is an integral part of overall well-being, fitting within the broader notion of mental health and directly contributing to a number of employment and workplace outcomes. The paper argued that employees with disabilities may end up in less pleasant workplaces compelled by discrimination and other restrictions. In workplaces with employers and co-worker practices and attitudes less befitting of employees with disabilities, wrong perceptions about people with disabilities may create strained interpersonal relations, which may impact workplace JS adversely. Employees with disabilities may take the brunt of the adverse impact on JS, being at the receiving end of poor workplace practices and 
attitudes. On the other hand, if employees without disabilities with discriminating attitudes or who are resentful of co-workers with disabilities are unable to sort away, they may be the ones taking the brunt of the adverse impact on JS feeling stuck.

The review of related literature highlighted that: (i) workplaces with respondents with disabilities report lower JS, (ii) workplace JS may decline with the degree of WD, (iii) the decline in JS may be stronger in workplaces with less accepting 'corporate culture', and (iv) the evidence on which group of workers (those with or without disabilities) take the brunt of the reduction in JS associated with WD is at best mixed. The paper used rich data from the 2011 WERS and carried out investigations deploying several empirical approaches to test the hypotheses proposed. The results obtained are robust to alternative econometric specifications and confirm the patterns observed from the raw data. Specifically: (i) workplaces with employees with disabilities report lower JS vis-à-vis workplaces without such respondents, (ii) workplace ownership status based sub-group analysis reveals that the adverse link found is specific to private sector workplaces, (iii) within private sector workplaces with a mix of respondents, workplace JS of respondents without disabilities is found to decline with the percentage of respondents with disabilities, and (iv) disability friendly workplace policies and practices are found to increase (reduce) the JS of respondents with (without) disabilities in the private sector.

That the adverse link between JS and WD found is specific to workplaces in the private sector suggests that the sector may have to go some way towards dealing with issues of workplace disability more efficiently. In particular, there may be a role for promoting a corporate culture that is more suitable to the needs of a diverse group of employees. In this respect, it is worth reiterating the point Scheur et al. (2014) and Kochan et al. (2003) make concerning the role that formal training and other informal conducts may play in promoting managers' and co-workers' awareness of the value of accommodating all employees and championing diversity in workplaces so that their composition resembles more like the broader workforce and/or society.

The paper is rigorous in many ways, including the rich data used and the alternative empirical approaches deployed, which have confirmed the robustness of the results obtained. This is reassuring in many ways. On the other hand, there are some caveats worth pointing. First, the nine domains of JS considered do not directly monitor worker attitude towards issues of workplace disability. We may, therefore, be measuring this indirectly at best. Secondly, although the results obtained are very 
much in line with the patterns observed from the raw data as well as being robust across the different specifications, the reliance on the WERS2011 cross-section is unlikely to make them entirely clean of possible endogeneity problems. Given these, the findings in the paper may have to be read somewhat cautiously. 


\section{References}

Abowd, J., Kramarz, F. and Margolis, D. (1999), High wage workers and high wage firms, Econometrica, 67 (2), 251-333.

Acemoglu, D. (2001) Good Jobs versus Bad Jobs, Journal of Labor Economics, 19 (1), 1- 21.

Aigner, D. and Cain, G. (1977), Statistical Theories of Discrimination in Labour Markets, Industrial and Labour Relations Review, 30 (2), 175-187.

Akerlof, G. A. and Kranton, R. E. (2000), Economics and Identity, The Quarterly Journal of Economics, 115 (3), 715-753.

Akerlof, G., Rose, A. and Yellen, J. (1988), Job Switching and job satisfaction in the US labour market, Brooking Papers on Economic Activity, 2, 495-582.

Alesina, A. and La Ferrara, E. (2000), Participation in Heterogeneous Communities. Quarterly Journal of Economics, 115(3), 847-904.

Alesina, A. and La Ferrara, E. (2005), Ethnic Diversity and Economic Performance, Journal of Economic Literature, 43, 762-800

Argyle, M. (1989), The Social Psychology of Work, $2^{\text {nd }}$ edition, Penguin, Harmondsworth.

Arrow, K. (1972), Models of Job Discrimination, in Pascal, A. (ed.) Racial Discrimination in Economic Life, Lexington, Massachusetts.

Arrow, K. (1973), The theory of Discrimination, in Ashenfelter \& Rees (eds.) Discrimination in Labor Markets, Princeton: Princeton University Press.

Baldwin, M. and Schumacher, E. (2002), A Note on Job Mobility among Workers with Disabilities. Industrial Relations, 41,430-441.

Baumberg, B., Jones, M. and Wass, V. (2015), Disability prevalence and disabilityrelated employment gaps in the UK 1998-2012: Different trends in different surveys? Social Science \& Medicine, 141, 72-81.

Becker, G. (1971), The Economics of Discrimination, University of Chicago Press.

Berthoud, R. (2006), The Employment Rates of Disabled People. DWP Research Report 298. London: Department for Work and Pensions

Berthoud, R. (2008), Disability employment penalties in Britain. Work Employment Society, 22 (1), $129-148$.

Berthoud, R. (2011), Trends in the Employment of Disabled People in Britain. ISER Working Paper Series No. 2011-03, Institute for Social and Economic Research.

Berthoud, R. and Blekesaune, M. (2007), Persistent Employment Disadvantage. DWP Research Report 416. London: Department for Work and Pensions.

Black, C. (2008), Working for a healthier tomorrow, Dame Carol Black's Review of the health of Britain's working age population, (https://www.gov.uk/government/uploads/system/uploads/attachment_data/file/2097 82/hwwb-working-for-a-healthier-tomorrow.pdf, accessed $17^{\text {th }}$ March 2016)

Blekesaune, M. (2007), Have Some European Countries Been More Successful At Employing Disabled People Than Others? ISER Working Paper 2007-23

Burke, R. (1999), Disability and women's work experiences: an exploratory study, International Journal of Sociology and Social Policy, 19 (12), 21-33.

Clark, A., Georgellis, Y and Sanfey, P (1998), Job satisfaction, wage changes, and quits, Research in Labour Economics, 17, 95-121.

Department for Business, Innovation and Skills; Advisory, Conciliation and Arbitration Service, and National Institute of Economic and Social Research. 
(2015). Workplace Employee Relations Survey, 2011. 6th Edition. UK Data Service. SN: 7226.

Dolan, P., Layard, R. and Metcalfe, R. (2011), Measuring Subjective Wellbeing for Public Policy, Centre for Economic Performance, LSE, London ( http://cep.lse.ac.uk/pubs/download/special/cepsp23.pdf, accessed $17^{\text {th }}$ April 2016)

DWP (2014), Statistics: Disability facts and figures, Department for Work \& Pensions, Office for Disability Issues (https://www.gov.uk/government/statistics/disability-facts-and-figures accessed on 28-Oct-15)

EHRC (2008), Insight: Work fit for all - disability, health and the experience of negative treatment in the British workplace.

Hamermesh, D. (2001), The Changing Distribution of Job Satisfaction, Human Resources, 36 (1), 1-30.

HSLC (2016), The Equality Act 2010: the impact on disabled people, House of Lords Select Committee on the Equality Act 2010 \& Disability, Report of Session 2015-16

(http://www.publications.parliament.uk/pa/ld201516/ldselect/ldeqact/117/117.pdf accessed on 30-June-16).

HSE (2009), Historical picture: Workplace injury and ill health trends following the introduction of the Health and Safety at Work Act 1974, http://www.hse.gov.uk/STATISTICS/history/index.htm (accessed 24/2/16).

Iaffaldano, M. and Muchinsky, P. (1985), Job Satisfaction and Job Performance: A Meta-Analysis, Psychological Bulletin, 97 (2), 251-273.

Jones, M. (2006), Is there employment discrimination against the disabled? Economic Letters, 92, 32-37.

Jones, M. (2008), Disability and the labour market: a review of the empirical evidence. Journal of Economic Studies, 35 (5), 405-424.

Jones, M. (2016), Disability and perceptions of work and management, British Journal of Industrial Relations, 54 (1), 83-113.

Jones, M., Latreille, P. and Sloane, P. (2006), Disability, Gender and the British Labour Market, Oxford Economic Papers, 58, 407-449

Jones, M. and Latreille, P. (2010), Disability and earnings: are employer characteristics important? Economics Letters, 106, 191-194.

Jones, M., Mavromaras, K., Sloane, P. and Zhang, W. (2014) Disability, job mismatch, earnings and job satisfaction in Australia, Cambridge Journal of Economics, 38, 1221-1246.

Kahneman, D. and Krueger, A. (2006), Developments in the Measurement of Subjective Well-Being, Journal of Economic Perspective, 20 (1), 3-24.

Kidd, M., Sloane, P. and Ferko, I. (2000), Disability and the labour market: an analysis of British males, Journal of Health Economics, 19, 961-981.

Kochan T, Bezrukova K, Ely R, Jackson S, Joshi A, Jehn K, Leonard J, Levine D and Thomas D (2003), The Effects of Diversity on Business Performance: Report of the Diversity Research Work. Human Resource Management, 42 (1), 321.

Lang, K. (1986), A Language Theory of Discrimination. The Quarterly Journal of Economics, May 1986, 101 (2), 363-382.

Layard, R. (2004), Good Jobs and Bad Jobs. CEP Occasional Paper No. 19, Centre for Economic Performance, LSE.

Lazear, E. (1999), Globalisation and the market for team-mates. The Economic Journal, 109, C15-C40. 
Levy-Garboua L, Montmarquette C and Simonnet V (2007), Job satisfaction and quits: Theory and evidence from the German socioeconomic panel, Labour Economics, 14 (2), 251 - 268.

Madden, D. (2004), Labour market discrimination on the basis of health: an application to UK data. Applied Economics, 36, 421-442.

Ostroff, C (1992), The Relationship Between Satisfaction, Attitudes, and Performance: An Organization Level Analysis, Journal of Applied Psychology, 77 (6), 963-974.

Oswald, A. (2010), Emotional prosperity and the Stiglitz Commission, British Journal of Industrial Relations, 48 (4), 651-69.

Pegan, R. and Malo, M. (2008), Job satisfaction and disability: lower expectations about jobs or a matter of health? Spanish Economic Review, 11, 51-74.

Perales, F., and Tomaszewski, W. (forthcoming), Happier with the same: job satisfaction of disadvantage workers, British Journal of Industrial Relations, doi: 10.1111/bjir.12152.

Rode, J. (2004), Job Satisfaction and life satisfaction revisited: a longitudinal test of an integrated model. Human Relations, 57 (9), 1205 - 1230.

Schur, L., Kruse, D., Blasi, J and Blanck, P. (2009), Is disability disabling in all workplaces? Workplace disparities and corporate culture, Industrial Relations, 48 (3), 381-410.

Schur, L., Kruse, D. and Blanck, P. (2013), People With Disabilities Sidelined or Mainsttreamed? Cambridge Disability Law and Policy Series, Cambridge University Press.

Schur, L., Nishii, L., Adya, M., Kruse, D., Bruyere, S. and Blanck, P. (2014), Accommodating Employees With and Without Disabilities, Human Resource Management, 53 (4), 593-621.

Smith, A. and Twomey, B. (2002), Labour Market Experiences of People with Disability. National Statistics Feature, Office of National Statistics

Sousa-Poza, A. and Sousa-Poza, A. (2000), Well-being at work: a cross-national analysis of the levels and determinants of job satisfaction, Journal of Socioeconomics, 29, 517-538.

Stiglitz, J. Sen, A. and Fitoussi, JP (2009), Report by the Commission on the Measurement of Economic Performance and Social Progress, Commission on the Measurement of Economic Performance and Social Progress (http://www.stiglitz-sen-fitoussi.fr/en/index.htm, accessed 17 ${ }^{\text {th }}$ April 2016)

Stone-Romero, E., Stone, D. and Lukaszewshi, K (2006), The Influence of Disability on Role-Taking in Organizations. In Konard, A., Prasad, P. and Pringle, J. (eds.) Handbook of Workplace Diversity, Sage Publications Ltd, London.

Uppal, S. (2005), Disability, workplace characteristics and job satisfaction, International Journal of Manpower, 26 (4), 336-349.

Van Wanrooy, B., Bewley, H., Bryson, A., Forth, J., Freeth, S., Stokes, L. and Wood, S. (2013), Employment Relations in the Shadow of Recession: findings from the 2011 Workplace Employment Relations Study, Palgrave, Macmillan.

Vickerstaff, S; Phillipson, C and Wilkie, R (2012), Work Health and Wellbeing. Bristol: Policy Press.

Warr, P. (1994), Conceptual framework for the study of work and mental health, Work and Stress, 8, $84-97$.

Warr, P. (1999), Well-being and the Workplace. In Kahneman, D., Diener, E. and Schwarz, N. (eds.), Well-being: the foundations of hedonic psychology, Russell Sage Foundation, New York. 
Table 1: Workplace-level average domain-specific and overall JS outcomes, all workplaces and by workplace disability \& ownership status

\begin{tabular}{|c|c|c|c|c|c|c|c|}
\hline & $\begin{array}{l}\text { All } \\
\text { workplaces }\end{array}$ & $\begin{array}{l}\text { Those w/out } \\
\text { respondents with } \\
\text { disabilities } \\
\text { (2) } \\
\end{array}$ & $\begin{array}{l}\text { Those with } \\
\text { respondent with } \\
\text { disabilities } \\
\text { (3) } \\
\end{array}$ & $\begin{array}{l}\text { Diff } \\
(2-3)\end{array}$ & $\begin{array}{l}\text { Private } \\
\text { workplaces } \\
\text { (5) }\end{array}$ & $\begin{array}{l}\text { Public } \\
\text { workplaces } \\
\text { (6) }\end{array}$ & $\begin{array}{l}\text { Diff } \\
(5-6)\end{array}$ \\
\hline Sense of achievement & 3.87 & 3.91 & 3.85 & $0.057 * *$ & 3.88 & 3.87 & 0.010 \\
\hline Scope for using own initiative & 3.92 & 3.98 & 3.87 & $0.113 * * *$ & 3.95 & 3.86 & $0.085 * * *$ \\
\hline Amount of influence over the job & 3.65 & 3.74 & 3.58 & $0.163 * * *$ & 3.71 & 3.51 & $0.193 * * *$ \\
\hline Training received & 3.43 & 3.47 & 3.40 & $0.069^{* *}$ & 3.46 & 3.37 & $0.087 * * *$ \\
\hline Opportunity to develop one's skills & 3.41 & 3.47 & 3.37 & $0.108 * * *$ & 3.45 & 3.33 & $0.122 * * *$ \\
\hline Amount of pay received & 3.03 & 3.08 & 2.99 & $0.085 * * *$ & 3.05 & 2.99 & $0.065^{* *}$ \\
\hline Job security & 3.46 & 3.54 & 3.39 & $0.147 * * *$ & 3.58 & 3.18 & $0.401 * * *$ \\
\hline The work itself & 3.88 & 3.92 & 3.84 & $0.074 * * *$ & 3.89 & 3.85 & 0.033 \\
\hline Involvement in decision making & 3.27 & 3.38 & 3.19 & $0.189 * * *$ & 3.34 & 3.13 & $0.211 * * *$ \\
\hline Overall satisfaction & 31.93 & 32.48 & 31.48 & $1.005 * * *$ & 32.30 & 31.09 & $1.207 * * *$ \\
\hline No. of workplaces & 1769 & 785 & 984 & & 549 & 1220 & \\
\hline
\end{tabular}


Table 2: Within workplace average JS differential between respondents with and without disabilities, workplaces with a mix of respondents and by ownership status of respondents with a mix of respondents

\begin{tabular}{|c|c|c|c|c|c|c|c|c|c|}
\hline & \multicolumn{4}{|c|}{ Respondents w/out a disability } & \multicolumn{4}{|c|}{ Respondents with disabilities } & \multirow[t]{2}{*}{ Diff $(1-5)$} \\
\hline & $\begin{array}{l}\text { All } \\
\text { workplace } \\
\text { s } \\
(1)\end{array}$ & $\begin{array}{l}\text { Private } \\
\text { workplaces } \\
\text { (2) }\end{array}$ & $\begin{array}{l}\text { Public } \\
\text { workplac } \\
\text { es (3) }\end{array}$ & $\begin{array}{l}\text { Diff } \\
(2-3)\end{array}$ & $\begin{array}{l}\text { All } \\
\text { workplaces } \\
(5)\end{array}$ & $\begin{array}{l}\text { Private } \\
\text { workplaces } \\
\text { (6) }\end{array}$ & $\begin{array}{l}\text { Public } \\
\text { workplaces } \\
\text { (7) }\end{array}$ & $\begin{array}{l}\text { Diff } \\
(6-7)\end{array}$ & \\
\hline Sense of achievement & 3.87 & 3.88 & 3.86 & 0.023 & 3.70 & 3.70 & 3.70 & -0.002 & $0.167 * * *$ \\
\hline Scope for using own initiative & 3.90 & 3.93 & 3.85 & $0.074 * * *$ & 3.71 & 3.74 & 3.67 & 0.073 & $0.188 * * *$ \\
\hline Amount of influence over the job & 3.61 & 3.68 & 3.50 & $0.182 * * *$ & 3.38 & 3.45 & 3.26 & $0.194 * * *$ & $0.234 * * *$ \\
\hline Training received & 3.44 & 3.47 & 3.39 & $0.087 * * *$ & 3.17 & 3.24 & 3.07 & $0.175 * * *$ & $0.265 * * *$ \\
\hline Opportunity to develop one's skills & 3.40 & 3.45 & 3.33 & $0.116^{* * *}$ & 3.09 & 3.16 & 2.98 & $0.175^{* * *}$ & $0.313 * * *$ \\
\hline Amount of pay received & 3.02 & 3.04 & 2.99 & $0.055^{*}$ & 2.81 & 2.85 & 2.74 & 0.100 & $0.213 * * *$ \\
\hline Job security & 3.42 & 3.57 & 3.19 & $0.375^{* * *}$ & 3.19 & 3.34 & 2.95 & $0.399 * * *$ & $0.233 * * *$ \\
\hline The work itself & 3.86 & 3.88 & 3.83 & $0.047 *$ & 3.70 & 3.73 & 3.65 & 0.078 & $0.161 * * *$ \\
\hline Involvement in decision making & 3.23 & 3.30 & 3.11 & $0.190^{* * *}$ & 2.95 & 3.01 & 2.85 & $0.165^{* * *}$ & $0.279 * * *$ \\
\hline Overall satisfaction & 31.75 & 32.20 & 31.05 & $1.149 * * *$ & 29.69 & 30.23 & 28.87 & $1.357 * * *$ & $2.054 * * *$ \\
\hline No. of workplaces & 970 & 587 & 383 & & 970 & 587 & 383 & & \\
\hline
\end{tabular}


Table 3: Disability friendly workplace policies and practices, workplaces with all and mixed respondents as well as by WD and ownership status

\begin{tabular}{|c|c|c|c|c|c|c|c|c|c|c|c|}
\hline \multirow[b]{2}{*}{ Workplace .... } & \multicolumn{7}{|c|}{ All workplaces } & \multicolumn{4}{|c|}{ Workplaces with mixed respondents } \\
\hline & $\begin{array}{l}\text { All } \\
(1)\end{array}$ & $\begin{array}{l}\text { Those w/out } \\
\text { respondents } \\
\text { with } \\
\text { disabilities } \\
\text { (2) }\end{array}$ & $\begin{array}{l}\text { Those with } \\
\text { respondents } \\
\text { with } \\
\text { disabilities } \\
\text { (3) }\end{array}$ & Diff $(2-3)$ & $\begin{array}{l}\text { Public } \\
(5)\end{array}$ & $\begin{array}{l}\text { Private } \\
(6)\end{array}$ & $\begin{array}{l}\text { Diff } \\
(5-6)\end{array}$ & $\begin{array}{l}\text { All } \\
(8)\end{array}$ & $\begin{array}{l}\text { Public } \\
\text { (9) }\end{array}$ & $\begin{array}{l}\text { Private } \\
(10)\end{array}$ & $\begin{array}{l}\text { Diff } \\
(9-10)\end{array}$ \\
\hline $\begin{array}{l}\text { Is covered by formal strategic plan covering employee } \\
\text { diversity }(0 / 1)\end{array}$ & 0.50 & 0.43 & 0.56 & $-0.124 * * *$ & 0.63 & 0.45 & $0.183 * * *$ & 0.56 & 0.65 & 0.50 & $0.143 * * *$ \\
\hline $\begin{array}{l}\text { Has formal written policy explicitly mentioning } \\
\text { disability equality }(0 / 1)\end{array}$ & 0.80 & 0.71 & 0.86 & $-0.145^{* * *}$ & 0.92 & 0.74 & $0.183 * * *$ & 0.86 & 0.92 & 0.83 & $0.098 * * *$ \\
\hline $\begin{array}{l}\text { Monitors promotion to identify indirect discrimination } \\
\text { by disability }(0 / 1)\end{array}$ & 0.17 & 0.12 & 0.21 & $-0.093 * * *$ & 0.37 & 0.08 & $0.288 * * *$ & 0.22 & 0.39 & 0.11 & $0.279 * * *$ \\
\hline $\begin{array}{l}\text { Reviews promotions to identify indirect discrimination } \\
\text { by disability }(0 / 1)\end{array}$ & 0.19 & 0.14 & 0.23 & $-0.084 * * *$ & 0.33 & 0.13 & $0.206 * * *$ & 0.23 & 0.33 & 0.16 & $0.174 * * *$ \\
\hline $\begin{array}{l}\text { Reviews relative pay to identify indirect discrimination } \\
\text { by disability }(0 / 1)\end{array}$ & 0.10 & 0.07 & 0.12 & $-0.048 * * *$ & 0.20 & 0.05 & $0.147 * * *$ & 0.12 & 0.20 & 0.07 & $0.123^{* * *}$ \\
\hline $\begin{array}{l}\text { Has special procedures to encourage those with } \\
\text { disabilities when filling vacancies }(0 / 1)\end{array}$ & 0.21 & 0.15 & 0.27 & $-0.120 * * *$ & 0.44 & 0.11 & $0.327 * * *$ & 0.27 & 0.46 & 0.14 & $0.325 * * *$ \\
\hline $\begin{array}{l}\text { Has made formal assessment of accessibility to those } \\
\text { with disabilities }(0 / 1)\end{array}$ & 0.65 & 0.58 & 0.71 & $-0.136 * * *$ & 0.86 & 0.56 & $0.302 * * *$ & 0.71 & 0.86 & 0.62 & $0.248 * * *$ \\
\hline Count of all policies and practices & 2.62 & 2.21 & 2.96 & $-0.750 * * *$ & 3.75 & 2.12 & $1.637 * * *$ & 2.98 & 3.82 & 2.43 & $1.391 * * *$ \\
\hline No. of workplaces & 1769 & 785 & 984 & & 549 & 1220 & & 970 & 383 & 587 & \\
\hline
\end{tabular}


Table 4: Estimates of workplace overall JS and WD, all workplaces

\begin{tabular}{|c|c|c|c|c|c|c|c|c|c|}
\hline \multirow[b]{2}{*}{$\overline{\mathrm{WD}(0 / 1)}$} & \multicolumn{3}{|c|}{ All } & \multicolumn{3}{|c|}{ Private } & \multicolumn{3}{|c|}{ Public } \\
\hline & $-0.980 * * *$ & $-0.491 *$ & $-0.494 *$ & $-1.079 * * *$ & $-0.883 * * *$ & $-0.855^{* * *}$ & -0.655 & -0.281 & -0.250 \\
\hline & $(0.289)$ & $(0.253)$ & $(0.252)$ & $(0.377)$ & $(0.318)$ & $(0.319)$ & $(0.414)$ & $(0.385)$ & $(0.378)$ \\
\hline \multirow{2}{*}{ Employees on Minimum Wage (\%) } & & 0.009 & 0.009 & & 0.007 & 0.007 & & 0.001 & 0.000 \\
\hline & & $(0.007)$ & $(0.007)$ & & $(0.008)$ & $(0.007)$ & & $(0.013)$ & $(0.013)$ \\
\hline \multirow{2}{*}{ Log workplace age } & & 0.030 & 0.026 & & 0.019 & -0.000 & & 0.013 & 0.021 \\
\hline & & $(0.097)$ & $(0.097)$ & & $(0.134)$ & $(0.132)$ & & $(0.148)$ & $(0.149)$ \\
\hline \multirow[t]{2}{*}{ Single establishment } & & 0.053 & 0.029 & & 0.539 & 0.481 & & -0.263 & -0.150 \\
\hline & & $(0.305)$ & $(0.307)$ & & $(0.420)$ & $(0.409)$ & & $(0.438)$ & $(0.437)$ \\
\hline \multirow[t]{2}{*}{ Private establishment } & & $1.828 * * *$ & $1.783 * * *$ & & & & & & \\
\hline & & $(0.284)$ & $(0.287)$ & & & & & & \\
\hline \multicolumn{10}{|l|}{ Workplace size (base 5 to 9 employees) } \\
\hline \multirow[t]{2}{*}{ 10-24 employees } & & $-1.504 * * *$ & $-1.493 * * *$ & & $-1.445 * * *$ & $-1.418 * * *$ & & $-1.921 *$ & $-1.976^{*}$ \\
\hline & & $(0.493)$ & $(0.494)$ & & $(0.537)$ & $(0.539)$ & & $(1.108)$ & (1.113) \\
\hline \multirow[t]{2}{*}{ 25-49 employees } & & $-2.599 * * *$ & $-2.589 * * *$ & & $-3.266 * * *$ & $-3.203^{* * *}$ & & $-1.680 *$ & $-1.650 *$ \\
\hline & & $(0.729)$ & $(0.725)$ & & $(0.953)$ & $(0.934)$ & & $(0.975)$ & $(0.985)$ \\
\hline \multirow{2}{*}{ 50-99 employees } & & $-2.737 * * *$ & $-2.712 * * *$ & & $-2.882 * * *$ & $-2.790 * * *$ & & $-2.618 * * *$ & $-2.678 * * *$ \\
\hline & & $(0.575)$ & $(0.569)$ & & $(0.760)$ & $(0.723)$ & & $(1.009)$ & $(1.012)$ \\
\hline \multirow[t]{2}{*}{ 100-199 employees } & & $-2.268 * * *$ & $-2.239 * * *$ & & $-1.771 * * *$ & $-1.644 * * *$ & & $-3.439 * * *$ & $-3.459 * * *$ \\
\hline & & $(0.470)$ & $(0.476)$ & & $(0.523)$ & $(0.548)$ & & $(0.984)$ & $(0.986)$ \\
\hline \multirow[t]{2}{*}{ 200-499 employees } & & $-2.606^{* * *}$ & $-2.554 * * *$ & & $-2.192 * * *$ & $-2.040 * * *$ & & $-3.153 * * *$ & $-3.307 * * *$ \\
\hline & & $(0.448)$ & $(0.461)$ & & $(0.557)$ & $(0.589)$ & & $(0.974)$ & $(0.979)$ \\
\hline \multirow{2}{*}{ 500-999 employees } & & $-2.506^{* * *}$ & $-2.444 * * *$ & & $-1.866 * * *$ & $-1.733^{* * *}$ & & $-3.290 * * *$ & $-3.545 * * *$ \\
\hline & & $(0.492)$ & $(0.512)$ & & $(0.568)$ & $(0.594)$ & & $(1.025)$ & $(1.034)$ \\
\hline \multirow[t]{2}{*}{ 1000-1999 employees } & & $-2.761 * * *$ & $-2.672 * * *$ & & $-1.878 * * *$ & $-1.719 * * *$ & & $-3.139 * * *$ & $-3.468 * * *$ \\
\hline & & $(0.453)$ & $(0.476)$ & & $(0.616)$ & $(0.641)$ & & $(0.946)$ & $(0.960)$ \\
\hline \multirow[t]{2}{*}{ 2000+ employees } & & $-1.959 * * *$ & $-1.853 * * *$ & & $-2.010 * * *$ & $-1.747 * * *$ & & $-1.785^{*}$ & $-2.155^{* *}$ \\
\hline & & $(0.469)$ & $(0.503)$ & & $(0.587)$ & $(0.655)$ & & $(1.011)$ & $(1.035)$ \\
\hline \multicolumn{10}{|l|}{ Industry (base manufacturing) } \\
\hline \multirow[t]{2}{*}{ Construction } & & 0.445 & 0.493 & & 0.083 & 0.136 & & $-3.079 * *$ & $-3.196 * * *$ \\
\hline & & $(0.783)$ & $(0.799)$ & & $(1.108)$ & $(1.112)$ & & $(1.199)$ & $(1.232)$ \\
\hline \multirow[t]{2}{*}{ Whole sale \& retail trade } & & $0.765^{*}$ & $0.779^{*}$ & & $0.942 *$ & $0.934^{*}$ & & $-7.726 * * *$ & $-7.237 * * *$ \\
\hline & & $(0.455)$ & $(0.459)$ & & $(0.484)$ & $(0.487)$ & & $(1.167)$ & $(1.235)$ \\
\hline \multirow[t]{2}{*}{ Hotels, restaurants \& transport services } & & -0.715 & -0.706 & & -0.205 & -0.230 & & $-5.390 * * *$ & $-5.281 * * *$ \\
\hline & & $(0.607)$ & $(0.602)$ & & $(0.626)$ & $(0.613)$ & & $(0.857)$ & $(0.879)$ \\
\hline Finance $\&$ business services & & $1.264 * * *$ & $1.280 * * *$ & & $1.303 * * *$ & $1.334 * * *$ & & -1.034 & -0.953 \\
\hline
\end{tabular}




\begin{tabular}{|c|c|c|c|c|c|c|c|c|c|}
\hline & & $(0.463)$ & $(0.469)$ & & $(0.499)$ & $(0.503)$ & & $(0.995)$ & $(0.927)$ \\
\hline \multirow[t]{2}{*}{ Public and community services } & & $1.262 * * *$ & $1.302 * * *$ & & $1.710 * * *$ & $1.757 * * *$ & & $-3.217 * * *$ & $-3.209 * * *$ \\
\hline & & $(0.388)$ & $(0.401)$ & & $(0.430)$ & $(0.432)$ & & $(0.771)$ & $(0.799)$ \\
\hline \multirow{2}{*}{ Education } & & $2.335 * * *$ & $2.421 * * *$ & & $1.600 * * *$ & $1.898 * * *$ & & -1.212 & -1.267 \\
\hline & & $(0.460)$ & $(0.490)$ & & $(0.604)$ & $(0.659)$ & & $(0.774)$ & $(0.809)$ \\
\hline \multirow[t]{2}{*}{ Health } & & $2.199 * * *$ & $2.232 * * *$ & & $2.146^{* * *}$ & $2.245^{* * *}$ & & $-2.275 * * *$ & $-2.202 * * *$ \\
\hline & & $(0.419)$ & $(0.430)$ & & $(0.515)$ & $(0.539)$ & & $(0.773)$ & $(0.801)$ \\
\hline \multicolumn{10}{|l|}{ Region (base, North East) } \\
\hline \multirow[t]{2}{*}{ North West } & & $-1.152 * *$ & $-1.165^{* *}$ & & $-1.617 * *$ & $-1.659 * *$ & & -0.562 & -0.533 \\
\hline & & $(0.524)$ & $(0.521)$ & & $(0.787)$ & $(0.757)$ & & $(0.721)$ & $(0.746)$ \\
\hline \multirow[t]{2}{*}{ Yorkshire \& the Humber } & & -0.379 & -0.399 & & -0.547 & -0.602 & & -0.326 & -0.277 \\
\hline & & $(0.536)$ & $(0.528)$ & & $(0.828)$ & $(0.785)$ & & $(0.666)$ & $(0.697)$ \\
\hline \multirow[t]{2}{*}{ East Midlands } & & -0.226 & -0.228 & & -0.332 & -0.366 & & 0.299 & 0.302 \\
\hline & & $(0.602)$ & $(0.599)$ & & $(0.762)$ & $(0.732)$ & & $(0.898)$ & $(0.910)$ \\
\hline \multirow[t]{2}{*}{ West Midlands } & & $-1.461 * *$ & $-1.466^{* *}$ & & $-2.517 * * *$ & $-2.516^{* * *}$ & & -0.387 & -0.376 \\
\hline & & $(0.581)$ & $(0.578)$ & & $(0.829)$ & $(0.805)$ & & $(0.676)$ & $(0.712)$ \\
\hline \multirow[t]{2}{*}{ East of England } & & -0.215 & -0.256 & & -0.425 & -0.466 & & -0.107 & 0.064 \\
\hline & & $(0.523)$ & $(0.529)$ & & $(0.792)$ & $(0.770)$ & & $(0.645)$ & $(0.685)$ \\
\hline \multirow[t]{2}{*}{ London } & & -0.402 & -0.406 & & -1.244 & -1.230 & & 0.486 & 0.525 \\
\hline & & $(0.578)$ & $(0.575)$ & & (0.891) & $(0.867)$ & & $(0.743)$ & $(0.767)$ \\
\hline \multirow[t]{2}{*}{ South East } & & -0.856 & -0.887 & & $-1.588 * *$ & $-1.653^{* *}$ & & 0.198 & 0.300 \\
\hline & & $(0.556)$ & $(0.556)$ & & $(0.782)$ & $(0.750)$ & & $(0.698)$ & $(0.739)$ \\
\hline \multirow{2}{*}{ South West } & & -0.885 & -0.926 & & $-1.475^{*}$ & $-1.516^{*}$ & & -0.486 & -0.320 \\
\hline & & $(0.570)$ & $(0.572)$ & & $(0.832)$ & $(0.800)$ & & $(0.763)$ & $(0.773)$ \\
\hline \multirow[t]{2}{*}{ Scotland } & & $-1.056^{* *}$ & $-1.074 * *$ & & -0.962 & -1.030 & & -0.805 & -0.747 \\
\hline & & $(0.533)$ & $(0.533)$ & & $(0.701)$ & $(0.675)$ & & $(0.766)$ & $(0.802)$ \\
\hline \multirow[t]{2}{*}{ Wales } & & -0.733 & -0.747 & & -0.524 & -0.661 & & -0.299 & -0.259 \\
\hline & & $(0.572)$ & $(0.568)$ & & $(0.954)$ & $(0.941)$ & & $(0.684)$ & $(0.712)$ \\
\hline \multirow[t]{2}{*}{ Disability Friendly Policies \& Practices } & & & -0.044 & & & -0.118 & & & 0.138 \\
\hline & & & $(0.077)$ & & & $(0.121)$ & & & $(0.088)$ \\
\hline \multirow[t]{2}{*}{ Constant } & $31.909 * * *$ & $32.249 * * *$ & $32.373 * * *$ & $32.431 * * *$ & $34.255 * * *$ & $34.504 * * *$ & $31.282 * * *$ & $36.247 * * *$ & $35.702 * * *$ \\
\hline & $(0.253)$ & $(0.828)$ & $(0.836)$ & $(0.315)$ & $(1.041)$ & $(1.025)$ & $(0.372)$ & $(1.402)$ & $(1.478)$ \\
\hline R-squared & 0.032 & 0.222 & 0.222 & 0.036 & 0.223 & 0.226 & 0.016 & 0.286 & 0.292 \\
\hline No. of Workplaces & & 1,769 & & & 1,220 & & & 549 & \\
\hline
\end{tabular}

Robust standard errors in parentheses

Estimates use WERS2011 establishment survey weights. There are no public sector workplaces in the wholesale and retail industry.

$* * * \mathrm{p}<0.01, * * \mathrm{p}<0.05, * \mathrm{p}<0.1$ 
Table 5: Estimates of workplace overall JS and WD, workplaces with mixed respondents only

\begin{tabular}{|c|c|c|c|c|c|c|c|c|c|}
\hline \multirow{2}{*}{$\overline{\mathrm{WD}(\%)}$} & \multicolumn{3}{|c|}{ All } & \multicolumn{3}{|c|}{ Private } & \multicolumn{3}{|c|}{ Public } \\
\hline & -0.026 & -0.024 & -0.023 & $-0.077 * * *$ & $-0.066^{* * *}$ & $-0.068 * * *$ & 0.015 & 0.007 & 0.005 \\
\hline & $(0.016)$ & $(0.015)$ & $(0.015)$ & $(0.021)$ & $(0.016)$ & $(0.015)$ & $(0.018)$ & $(0.018)$ & $(0.018)$ \\
\hline \multirow{2}{*}{ Employees on Minimum Wage (\%) } & & 0.004 & 0.004 & & 0.007 & 0.006 & & 0.000 & -0.001 \\
\hline & & $(0.007)$ & $(0.007)$ & & $(0.009)$ & $(0.008)$ & & $(0.016)$ & $(0.016)$ \\
\hline \multirow[t]{2}{*}{ Log workplace age } & & -0.015 & -0.023 & & -0.098 & -0.158 & & -0.022 & -0.018 \\
\hline & & $(0.104)$ & $(0.104)$ & & $(0.147)$ & $(0.140)$ & & $(0.160)$ & $(0.159)$ \\
\hline \multirow[t]{2}{*}{ Single establishment } & & -0.301 & -0.362 & & 0.657 & 0.478 & & -0.645 & -0.549 \\
\hline & & $(0.310)$ & $(0.312)$ & & $(0.474)$ & $(0.438)$ & & $(0.396)$ & $(0.407)$ \\
\hline \multirow[t]{2}{*}{ Private establishment } & & $1.793 * * *$ & $1.710 * * *$ & & & & & & \\
\hline & & $(0.305)$ & $(0.309)$ & & & & & & \\
\hline \multicolumn{10}{|l|}{ Workplace size (base 5 to 9 employees) } \\
\hline \multirow[t]{2}{*}{ 10-24 employees } & & $-1.796 * *$ & $-1.785 * *$ & & $-2.447 * *$ & $-2.603 * * *$ & & -1.251 & -1.444 \\
\hline & & $(0.888)$ & $(0.887)$ & & $(0.964)$ & $(0.942)$ & & $(2.630)$ & $(2.622)$ \\
\hline \multirow[t]{2}{*}{ 25-49 employees } & & $-2.932 * *$ & $-2.960 * *$ & & $-4.576 * * *$ & $-4.632 * * *$ & & -0.827 & -0.873 \\
\hline & & $(1.245)$ & $(1.236)$ & & $(1.505)$ & $(1.428)$ & & $(2.499)$ & $(2.492)$ \\
\hline \multirow{2}{*}{ 50-99 employees } & & $-2.768 * * *$ & $-2.780 * * *$ & & $-3.597 * * *$ & $-3.768 * * *$ & & -1.879 & -1.980 \\
\hline & & $(0.866)$ & $(0.864)$ & & $(0.927)$ & $(0.897)$ & & $(2.534)$ & $(2.526)$ \\
\hline \multirow[t]{2}{*}{ 100-199 employees } & & $-2.472 * * *$ & $-2.449 * * *$ & & $-2.857 * * *$ & $-2.771 * * *$ & & -2.847 & -2.939 \\
\hline & & $(0.856)$ & $(0.857)$ & & $(0.915)$ & $(0.892)$ & & $(2.506)$ & $(2.498)$ \\
\hline \multirow[t]{2}{*}{ 200-499 employees } & & $-2.718^{* * *}$ & $-2.655 * * *$ & & $-2.764 * * *$ & $-2.658 * * *$ & & -2.555 & -2.741 \\
\hline & & $(0.825)$ & $(0.827)$ & & $(0.911)$ & $(0.889)$ & & $(2.510)$ & $(2.508)$ \\
\hline \multirow[t]{2}{*}{ 500-999 employees } & & $-2.758 * * *$ & $-2.689 * * *$ & & $-3.087 * * *$ & $-3.026 * * *$ & & -2.328 & -2.555 \\
\hline & & $(0.863)$ & $(0.867)$ & & $(0.913)$ & $(0.882)$ & & $(2.544)$ & $(2.545)$ \\
\hline \multirow[t]{2}{*}{ 1000-1999 employees } & & $-3.331 * * *$ & $-3.204 * * *$ & & $-3.674 * * *$ & $-3.636 * * *$ & & -2.344 & -2.633 \\
\hline & & $(0.881)$ & $(0.888)$ & & $(1.056)$ & (1.025) & & $(2.501)$ & (2.513) \\
\hline \multirow[t]{2}{*}{ 2000+ employees } & & $-2.131 * *$ & $-1.956 * *$ & & $-3.621 * * *$ & $-3.197 * * *$ & & -0.600 & -0.921 \\
\hline & & $(0.869)$ & $(0.883)$ & & $(1.037)$ & $(1.009)$ & & $(2.505)$ & $(2.526)$ \\
\hline \multicolumn{10}{|l|}{ Industry (base manufacturing) } \\
\hline \multirow[t]{2}{*}{ Construction } & & -0.001 & 0.122 & & -0.784 & -0.575 & & $-2.906 *$ & $-3.076^{*}$ \\
\hline & & $(1.040)$ & $(1.071)$ & & $(1.552)$ & $(1.581)$ & & $(1.595)$ & $(1.641)$ \\
\hline \multirow[t]{2}{*}{ Whole sale \& retail trade } & & $1.192 *$ & $1.230 *$ & & 0.673 & 0.668 & & & \\
\hline & & $(0.645)$ & $(0.656)$ & & $(0.677)$ & $(0.700)$ & & & \\
\hline \multirow[t]{2}{*}{ Hotels, restaurants \& transport services } & & -1.114 & -1.089 & & $-1.165^{*}$ & $-1.252 * *$ & & $-4.695 * * *$ & $-4.730 * * *$ \\
\hline & & $(0.691)$ & $(0.685)$ & & $(0.663)$ & $(0.625)$ & & $(1.287)$ & $(1.295)$ \\
\hline Finance $\&$ business services & & $1.508 * * *$ & $1.570 * * *$ & & 0.701 & $0.846^{*}$ & & -0.553 & -0.571 \\
\hline
\end{tabular}




\begin{tabular}{|c|c|c|c|c|c|c|c|c|c|}
\hline & & $(0.463)$ & $(0.477)$ & & $(0.498)$ & $(0.498)$ & & $(1.363)$ & $(1.315)$ \\
\hline \multirow[t]{2}{*}{ Public and community services } & & $1.169 * * *$ & $1.259 * * *$ & & $1.281 * * *$ & $1.385 * * *$ & & $-3.002 * *$ & $-3.110 * *$ \\
\hline & & $(0.451)$ & $(0.472)$ & & $(0.405)$ & $(0.414)$ & & $(1.253)$ & $(1.277)$ \\
\hline \multirow[t]{2}{*}{ Education } & & $2.219 * * *$ & $2.415 * * *$ & & 0.691 & $1.448 * *$ & & -0.830 & -0.991 \\
\hline & & $(0.515)$ & $(0.553)$ & & $(0.645)$ & $(0.674)$ & & $(1.230)$ & $(1.273)$ \\
\hline \multirow[t]{2}{*}{ Health } & & $2.440 * * *$ & $2.503 * * *$ & & $1.829 * * *$ & $2.016 * * *$ & & -1.834 & -1.889 \\
\hline & & $(0.490)$ & $(0.504)$ & & $(0.493)$ & $(0.501)$ & & $(1.151)$ & $(1.158)$ \\
\hline \multicolumn{10}{|l|}{ Region (base, North East) } \\
\hline \multirow[t]{2}{*}{ North West } & & -0.221 & -0.271 & & -0.177 & -0.587 & & -0.322 & -0.312 \\
\hline & & $(0.585)$ & $(0.581)$ & & $(0.536)$ & $(0.459)$ & & $(0.812)$ & $(0.835)$ \\
\hline \multirow[t]{2}{*}{ Yorkshire \& the Humber } & & 0.248 & 0.175 & & 0.755 & 0.285 & & -0.769 & -0.742 \\
\hline & & $(0.619)$ & $(0.598)$ & & $(0.752)$ & $(0.645)$ & & $(0.733)$ & $(0.764)$ \\
\hline \multirow[t]{2}{*}{ East Midlands } & & 0.716 & 0.690 & & 0.872 & 0.478 & & 0.831 & 0.817 \\
\hline & & $(0.625)$ & $(0.621)$ & & $(0.622)$ & $(0.544)$ & & $(0.901)$ & $(0.910)$ \\
\hline \multirow[t]{2}{*}{ West Midlands } & & $-1.132 *$ & $-1.148 *$ & & $-1.964 * * *$ & $-2.180 * * *$ & & -0.707 & -0.726 \\
\hline & & $(0.597)$ & $(0.595)$ & & $(0.589)$ & $(0.567)$ & & $(0.733)$ & $(0.760)$ \\
\hline \multirow{2}{*}{ East of England } & & 0.216 & 0.103 & & 0.389 & -0.011 & & -0.327 & -0.217 \\
\hline & & $(0.544)$ & $(0.550)$ & & $(0.654)$ & $(0.626)$ & & $(0.688)$ & $(0.727)$ \\
\hline \multirow[t]{2}{*}{ London } & & -0.460 & -0.496 & & -0.213 & -0.386 & & -0.321 & -0.283 \\
\hline & & $(0.625)$ & $(0.618)$ & & $(0.756)$ & $(0.677)$ & & $(0.823)$ & $(0.848)$ \\
\hline \multirow[t]{2}{*}{ South East } & & -0.462 & -0.547 & & $-1.057^{*}$ & $-1.417 * *$ & & 0.163 & 0.222 \\
\hline & & $(0.604)$ & $(0.607)$ & & $(0.625)$ & $(0.593)$ & & $(0.733)$ & $(0.769)$ \\
\hline \multirow[t]{2}{*}{ South West } & & -0.183 & -0.295 & & 0.576 & 0.194 & & -0.835 & -0.738 \\
\hline & & $(0.676)$ & $(0.679)$ & & $(0.925)$ & $(0.866)$ & & $(0.865)$ & $(0.875)$ \\
\hline \multirow[t]{2}{*}{ Scotland } & & -0.312 & -0.380 & & -0.090 & -0.548 & & -0.444 & -0.393 \\
\hline & & $(0.555)$ & $(0.552)$ & & $(0.486)$ & $(0.445)$ & & $(0.774)$ & $(0.813)$ \\
\hline \multirow[t]{2}{*}{ Wales } & & 0.164 & 0.123 & & 0.532 & -0.099 & & -0.082 & -0.096 \\
\hline & & $(0.595)$ & $(0.584)$ & & $(0.691)$ & $(0.679)$ & & $(0.772)$ & $(0.795)$ \\
\hline \multirow{2}{*}{\multicolumn{2}{|c|}{ Disability Friendly Policies \& Practices }} & & -0.086 & & & $-0.275^{* *}$ & & & 0.091 \\
\hline & & & $(0.086)$ & & & $(0.116)$ & & & $(0.092)$ \\
\hline \multirow[t]{2}{*}{ Constant } & $31.309 * * *$ & $32.041 * * *$ & $32.332 * * *$ & $32.337 * * *$ & $35.270 * * *$ & $36.508 * * *$ & $30.388 * * *$ & $34.826 * * *$ & $34.707 * * *$ \\
\hline & $(0.257)$ & $(1.245)$ & $(1.250)$ & $(0.329)$ & $(1.308)$ & $(1.242)$ & $(0.307)$ & $(2.938)$ & $(2.940)$ \\
\hline R-squared & 0.009 & 0.265 & 0.267 & 0.061 & 0.345 & 0.361 & 0.004 & 0.366 & 0.368 \\
\hline No. of Workplaces & & 970 & & & 587 & & & 383 & \\
\hline
\end{tabular}

Robust standard errors in parentheses

Estimates use WERS2011 establishment survey weights. There are no public sector workplaces in the wholesale and retail industry.

$* * * \mathrm{p}<0.01, * * \mathrm{p}<0.05, * \mathrm{p}<0.1$ 
Table 6: SUR estimates of workplace overall JS \& WD, workplaces with mixed respondents only

\begin{tabular}{|c|c|c|c|c|c|c|}
\hline & \multicolumn{2}{|c|}{ All } & \multicolumn{2}{|c|}{ Private } & \multicolumn{2}{|c|}{ Public } \\
\hline & $\begin{array}{l}\text { Respondents with } \\
\text { disabilities }\end{array}$ & $\begin{array}{l}\text { Respondents w/out } \\
\text { disabilities }\end{array}$ & $\begin{array}{l}\text { Respondents with } \\
\text { disabilities }\end{array}$ & $\begin{array}{l}\text { Respondents w/out } \\
\text { disabilities }\end{array}$ & $\begin{array}{l}\text { Respondents with } \\
\text { disabilities }\end{array}$ & $\begin{array}{l}\text { Respondents w/out } \\
\text { disabilities }\end{array}$ \\
\hline \multirow[t]{2}{*}{ WD $(\%)$} & -0.018 & -0.008 & -0.049 & $-0.055 * * *$ & 0.002 & 0.018 \\
\hline & $(0.039)$ & $(0.017)$ & $(0.049)$ & $(0.017)$ & $(0.055)$ & $(0.016)$ \\
\hline \multirow[t]{2}{*}{ Employees on Minimum Wage (\%) } & $0.041 * *$ & -0.007 & $0.052 * * *$ & -0.006 & 0.011 & -0.011 \\
\hline & $(0.017)$ & $(0.009)$ & $(0.015)$ & $(0.011)$ & $(0.042)$ & $(0.019)$ \\
\hline \multirow[t]{2}{*}{ Log workplace age } & $-1.108 * * *$ & 0.113 & $-1.351 * * *$ & -0.035 & $-1.121 *$ & 0.144 \\
\hline & $(0.344)$ & $(0.102)$ & $(0.309)$ & $(0.134)$ & $(0.584)$ & $(0.150)$ \\
\hline \multirow[t]{2}{*}{ Single establishment } & 0.117 & -0.299 & -0.005 & 0.382 & 0.529 & -0.330 \\
\hline & $(0.840)$ & $(0.337)$ & (1.327) & $(0.441)$ & (1.115) & $(0.424)$ \\
\hline \multirow[t]{2}{*}{ Private establishment } & $2.708 * * *$ & $1.504 * * *$ & & & & \\
\hline & $(0.782)$ & $(0.316)$ & & & & \\
\hline \multicolumn{7}{|c|}{ Workplace size (base 5 to 9 employees) } \\
\hline \multirow[t]{2}{*}{ 10-24 employees } & -0.473 & $-1.886^{* *}$ & -1.838 & $-2.736 * * *$ & 0.709 & -1.529 \\
\hline & $(1.721)$ & $(0.901)$ & (2.204) & $(0.919)$ & $(3.616)$ & $(2.406)$ \\
\hline \multirow[t]{2}{*}{ 25-49 employees } & -1.824 & $-3.199 * *$ & $-4.285^{*}$ & $-4.928 * * *$ & 0.415 & -0.950 \\
\hline & $(1.751)$ & $(1.293)$ & $(2.196)$ & $(1.455)$ & $(3.395)$ & $(2.225)$ \\
\hline \multirow[t]{2}{*}{ 50-99 employees } & -2.256 & $-2.643 * * *$ & -2.861 & $-3.905 * * *$ & -3.147 & -1.491 \\
\hline & $(1.756)$ & $(0.883)$ & $(2.118)$ & $(0.869)$ & (3.618) & (2.276) \\
\hline \multirow[t]{2}{*}{ 100-199 employees } & -1.462 & $-2.499 * * *$ & -1.843 & $-2.987 * * *$ & -2.600 & -2.732 \\
\hline & $(1.684)$ & $(0.854)$ & $(2.241)$ & $(0.862)$ & $(3.419)$ & (2.227) \\
\hline \multirow[t]{2}{*}{ 200-499 employees } & -1.714 & $-2.880 * * *$ & -2.344 & $-2.813 * * *$ & -1.817 & -3.037 \\
\hline & $(1.712)$ & $(0.840)$ & $(2.204)$ & $(0.866)$ & (3.468) & $(2.241)$ \\
\hline \multirow[t]{2}{*}{ 500-999 employees } & $-2.952 *$ & $-2.580 * * *$ & -2.731 & $-3.053 * * *$ & -4.783 & -2.214 \\
\hline & $(1.702)$ & $(0.867)$ & $(2.136)$ & $(0.847)$ & (3.443) & $(2.286)$ \\
\hline \multirow[t]{2}{*}{ 1000-1999 employees } & -2.056 & $-3.453 * * *$ & -3.612 & $-3.855 * * *$ & -2.412 & -2.842 \\
\hline & $(2.025)$ & $(0.866)$ & (2.893) & $(0.976)$ & (3.608) & $(2.236)$ \\
\hline \multirow[t]{2}{*}{ 2000+ employees } & 0.613 & $-2.210 * *$ & -0.992 & $-3.309 * * *$ & 0.566 & -1.190 \\
\hline & $(1.891)$ & $(0.892)$ & $(2.739)$ & $(1.040)$ & $(3.582)$ & $(2.260)$ \\
\hline \multicolumn{7}{|l|}{ Industry (base manufacturing) } \\
\hline \multirow[t]{2}{*}{ Construction } & -1.397 & 0.007 & -3.798 & 0.004 & -3.154 & $-6.010 * * *$ \\
\hline & $(2.302)$ & $(0.998)$ & $(3.155)$ & $(1.398)$ & $(4.425)$ & $(2.025)$ \\
\hline \multirow[t]{2}{*}{ Whole sale \& retail trade } & 0.442 & $1.434 * *$ & -0.767 & 0.978 & & \\
\hline & $(1.552)$ & $(0.668)$ & $(1.670)$ & $(0.705)$ & & \\
\hline \multirow[t]{2}{*}{ Hotels, restaurants \& transport services } & -1.929 & -0.804 & -1.543 & $-1.106^{*}$ & -6.619 & $-6.560 * * *$ \\
\hline & $(1.618)$ & $(0.658)$ & $(1.631)$ & $(0.600)$ & $(4.537)$ & $(1.764)$ \\
\hline
\end{tabular}




\begin{tabular}{|c|c|c|c|c|c|c|}
\hline Finance \& business services & -1.561 & $2.082 * * *$ & $-2.617 *$ & $1.461 * *$ & -1.255 & -2.740 \\
\hline & $(1.484)$ & $(0.547)$ & $(1.565)$ & $(0.575)$ & $(4.072)$ & $(1.785)$ \\
\hline \multirow[t]{2}{*}{ Public and community services } & -0.557 & $1.340 * * *$ & -0.906 & $1.580 * * *$ & -3.481 & $-5.527 * * *$ \\
\hline & $(1.257)$ & $(0.504)$ & $(1.273)$ & $(0.435)$ & $(4.122)$ & (1.712) \\
\hline \multirow[t]{2}{*}{ Education } & -0.084 & $2.619 * * *$ & 0.386 & $1.726 * *$ & -3.323 & $-3.160 *$ \\
\hline & $(1.429)$ & $(0.616)$ & $(2.037)$ & $(0.727)$ & $(4.220)$ & $(1.726)$ \\
\hline \multirow{2}{*}{ Health } & 0.871 & $2.612 * * *$ & 0.107 & $2.333 * * *$ & -2.260 & $-4.174 * *$ \\
\hline & $(1.299)$ & $(0.575)$ & $(1.456)$ & $(0.540)$ & (3.874) & $(1.705)$ \\
\hline \multicolumn{7}{|l|}{ Region (base, North East) } \\
\hline \multirow[t]{2}{*}{ North West } & $-2.117^{*}$ & -0.146 & -2.169 & -0.689 & -2.635 & -0.176 \\
\hline & $(1.202)$ & $(0.570)$ & $(1.333)$ & $(0.500)$ & $(1.774)$ & $(0.776)$ \\
\hline \multirow[t]{2}{*}{ Yorkshire \& the Humber } & -1.946 & 0.255 & -1.437 & 0.164 & $-3.082 * *$ & -0.635 \\
\hline & $(1.276)$ & $(0.624)$ & $(1.619)$ & $(0.654)$ & $(1.535)$ & $(0.834)$ \\
\hline \multirow[t]{2}{*}{ East Midlands } & $-3.556 * *$ & $1.259 * *$ & $-4.029 * *$ & 0.994 & -3.477 & 1.239 \\
\hline & $(1.438)$ & $(0.638)$ & $(1.612)$ & $(0.710)$ & $(2.393)$ & $(0.796)$ \\
\hline \multirow[t]{2}{*}{ West Midlands } & $-4.974 * * *$ & -0.595 & $-7.389 * * *$ & $-1.610 * *$ & -2.144 & -0.546 \\
\hline & $(1.281)$ & $(0.597)$ & $(1.390)$ & $(0.630)$ & $(1.430)$ & $(0.801)$ \\
\hline \multirow[t]{2}{*}{ East of England } & $-2.603 * *$ & 0.408 & $-4.121 * *$ & 0.181 & -2.437 & 0.154 \\
\hline & $(1.145)$ & $(0.592)$ & $(1.719)$ & $(0.669)$ & $(1.518)$ & $(0.764)$ \\
\hline \multirow[t]{2}{*}{ London } & -1.509 & -0.453 & -0.967 & -0.461 & -1.950 & -0.180 \\
\hline & $(1.846)$ & $(0.596)$ & $(1.592)$ & $(0.722)$ & $(2.466)$ & $(0.790)$ \\
\hline \multirow[t]{2}{*}{ South East } & -0.378 & -0.768 & 0.179 & $-2.028 * * *$ & -1.361 & 0.271 \\
\hline & $(1.316)$ & $(0.633)$ & $(1.663)$ & $(0.653)$ & $(1.833)$ & $(0.764)$ \\
\hline \multirow[t]{2}{*}{ South West } & -1.323 & -0.221 & 0.940 & -0.221 & $-2.758^{*}$ & -0.489 \\
\hline & $(1.120)$ & $(0.687)$ & $(1.483)$ & $(0.831)$ & $(1.420)$ & $(0.876)$ \\
\hline \multirow[t]{2}{*}{ Scotland } & $-2.022 *$ & -0.222 & -2.104 & -0.768 & -2.253 & -0.036 \\
\hline & $(1.089)$ & $(0.590)$ & $(1.419)$ & $(0.522)$ & $(1.615)$ & $(0.854)$ \\
\hline \multirow[t]{2}{*}{ Wales } & 0.067 & 0.270 & -1.946 & -0.048 & 0.599 & 0.049 \\
\hline & $(1.388)$ & $(0.579)$ & $(2.230)$ & $(0.557)$ & $(1.765)$ & $(0.801)$ \\
\hline \multirow[t]{2}{*}{ Disability Friendly Policies \& Practices } & $0.421 * *$ & -0.139 & 0.233 & $-0.373 * * *$ & $0.473 * *$ & 0.092 \\
\hline & $(0.177)$ & $(0.092)$ & $(0.313)$ & $(0.124)$ & $(0.237)$ & $(0.098)$ \\
\hline \multirow[t]{2}{*}{ Constant } & $34.009 * * *$ & $32.069 * * *$ & $39.727 * * *$ & $36.468 * * *$ & $37.177 * * *$ & $36.435 * * *$ \\
\hline & $(2.855)$ & $(1.295)$ & $(3.445)$ & $(1.241)$ & $(5.777)$ & $(2.990)$ \\
\hline Breusch-Pagan test of independence [Chi2(1)/Pr.] & & $2 / 0.000$ & & $/ 0.000$ & & 0.000 \\
\hline No. of Workplaces & & 70 & & 87 & & 83 \\
\hline
\end{tabular}

Robust standard errors in parentheses

Estimates use WERS2011 establishment survey weights. There are no public sector workplaces in the wholesale and retail industry.

$* * * \mathrm{p}<0.01, * * \mathrm{p}<0.05, * \mathrm{p}<0.1$ 


\section{Appendix}

Table A1: Descriptive statistics on outcome and control variables, ALL workplaces

\begin{tabular}{|c|c|c|c|c|c|c|c|c|c|c|c|c|}
\hline & \multicolumn{4}{|c|}{ All workplaces } & \multicolumn{4}{|c|}{$\begin{array}{l}\text { Workplaces w/out respondents } \\
\text { with disabilities }\end{array}$} & \multicolumn{4}{|c|}{$\begin{array}{l}\text { Workplaces with respondents with } \\
\text { disabilities }\end{array}$} \\
\hline & Mean & St. Dev & Min & Max & Mean & St. Dev & Min & Max & Mean & St. Dev & Min & $\operatorname{Max}$ \\
\hline \multicolumn{13}{|l|}{ Outcomes } \\
\hline Workplace Av JS & 31.93 & 3.66 & 13 & 45 & 32.48 & 4.04 & 13 & 45 & 31.48 & 3.26 & 13 & 44 \\
\hline Workplace Av JS, disabled & 29.76 & 6.08 & 9 & 45 & & & & & 29.76 & 6.08 & 9 & 45 \\
\hline Workplace Av JS, nondisabled & 32.08 & 3.59 & 13 & 45 & 32.48 & 4.04 & 13 & 45 & 31.75 & 3.15 & 18.9 & 41 \\
\hline \multicolumn{13}{|l|}{ Controls } \\
\hline Has respondents with disabilities $(0 / 1)$ & 0.56 & 0.50 & 0 & 1 & 0.00 & 0.00 & 0 & 0 & 1.00 & 0.00 & 1 & 1 \\
\hline$\%$ respondents with disabilities & 9.31 & 13.40 & 0 & 100 & 0.00 & 0.00 & 0 & 0 & 16.73 & 14.10 & 4.17 & 100 \\
\hline$\%$ on minimum wage & 5.91 & 16.54 & 0 & 100 & 7.94 & 18.95 & 0 & 100 & 4.29 & 14.14 & 0 & 100 \\
\hline Disability policies and practices & 2.62 & 1.76 & 0 & 7 & 2.21 & 1.68 & 0 & 7 & 2.96 & 1.74 & 0 & 7 \\
\hline Private establishment & 0.69 & 0.46 & 0 & 1 & 0.79 & 0.41 & 0 & 1 & 0.61 & 0.49 & 0 & 1 \\
\hline Single establishment & 0.29 & 0.45 & 0 & 1 & 0.35 & 0.48 & 0 & 1 & 0.24 & 0.43 & 0 & 1 \\
\hline Log workplace age & 3.17 & 1.05 & 0 & 6.80 & 3.07 & 1.03 & 0 & 6.80 & 3.25 & 1.07 & 0 & 6.6 \\
\hline Size5-9 & 0.11 & 0.31 & 0 & 1 & 0.18 & 0.39 & 0 & 1 & 0.05 & 0.22 & 0 & 1 \\
\hline Size10-24 & 0.19 & 0.39 & 0 & 1 & 0.29 & 0.45 & 0 & 1 & 0.11 & 0.31 & 0 & 1 \\
\hline size 25-49 & 0.15 & 0.35 & 0 & 1 & 0.14 & 0.35 & 0 & 1 & 0.15 & 0.36 & 0 & 1 \\
\hline size $50-99$ & 0.16 & 0.36 & 0 & 1 & 0.11 & 0.31 & 0 & 1 & 0.20 & 0.40 & 0 & 1 \\
\hline Size100-199 & 0.12 & 0.33 & 0 & 1 & 0.09 & 0.28 & 0 & 1 & 0.15 & 0.36 & 0 & 1 \\
\hline Size200-499 & 0.12 & 0.33 & 0 & 1 & 0.09 & 0.29 & 0 & 1 & 0.15 & 0.36 & 0 & 1 \\
\hline Size500-999 & 0.06 & 0.24 & 0 & 1 & 0.03 & 0.18 & 0 & 1 & 0.08 & 0.27 & 0 & 1 \\
\hline Size1000-1999 & 0.04 & 0.20 & 0 & 1 & 0.03 & 0.17 & 0 & 1 & 0.05 & 0.23 & 0 & 1 \\
\hline Size2000+ & 0.05 & 0.22 & 0 & 1 & 0.05 & 0.21 & 0 & 1 & 0.06 & 0.23 & 0 & 1 \\
\hline Manufacturing & 0.10 & 0.30 & 0 & 1 & 0.10 & 0.30 & 0 & 1 & 0.10 & 0.30 & 0 & 1 \\
\hline Construction & 0.03 & 0.18 & 0 & 1 & 0.04 & 0.19 & 0 & 1 & 0.03 & 0.17 & 0 & 1 \\
\hline Whole sale \& retail trade & 0.10 & 0.30 & 0 & 1 & 0.14 & 0.34 & 0 & 1 & 0.08 & 0.27 & 0 & 1 \\
\hline Hotels, restaurants \& transport services & 0.12 & 0.32 & 0 & 1 & 0.13 & 0.34 & 0 & 1 & 0.10 & 0.31 & 0 & 1 \\
\hline Finance \& business services & 0.14 & 0.34 & 0 & 1 & 0.18 & 0.38 & 0 & 1 & 0.10 & 0.31 & 0 & 1 \\
\hline Public and community services & 0.20 & 0.40 & 0 & 1 & 0.16 & 0.37 & 0 & 1 & 0.23 & 0.42 & 0 & 1 \\
\hline Education & 0.15 & 0.35 & 0 & 1 & 0.13 & 0.34 & 0 & 1 & 0.16 & 0.36 & 0 & 1 \\
\hline Health & 0.16 & 0.37 & 0 & 1 & 0.12 & 0.33 & 0 & 1 & 0.19 & 0.40 & 0 & 1 \\
\hline
\end{tabular}




\begin{tabular}{|c|c|c|c|c|c|c|c|c|c|c|c|c|}
\hline North East & 0.04 & 0.20 & 0 & 1 & 0.04 & 0.19 & 0 & 1 & 0.04 & 0.20 & 0 & 1 \\
\hline North West & 0.14 & 0.35 & 0 & 1 & 0.13 & 0.34 & 0 & 1 & 0.15 & 0.35 & 0 & 1 \\
\hline Yorkshire \& the Humber & 0.08 & 0.27 & 0 & 1 & 0.08 & 0.26 & 0 & 1 & 0.08 & 0.27 & 0 & 1 \\
\hline East Midlands & 0.07 & 0.25 & 0 & 1 & 0.06 & 0.24 & 0 & 1 & 0.07 & 0.25 & 0 & 1 \\
\hline West Midlands & 0.08 & 0.28 & 0 & 1 & 0.08 & 0.28 & 0 & 1 & 0.09 & 0.28 & 0 & 1 \\
\hline East of England & 0.08 & 0.27 & 0 & 1 & 0.07 & 0.25 & 0 & 1 & 0.09 & 0.29 & 0 & 1 \\
\hline London & 0.12 & 0.33 & 0 & 1 & 0.15 & 0.36 & 0 & 1 & 0.09 & 0.29 & 0 & 1 \\
\hline South East & 0.14 & 0.35 & 0 & 1 & 0.15 & 0.36 & 0 & 1 & 0.13 & 0.34 & 0 & 1 \\
\hline South West & 0.09 & 0.28 & 0 & 1 & 0.09 & 0.29 & 0 & 1 & 0.08 & 0.28 & 0 & 1 \\
\hline Scotland & 0.11 & 0.31 & 0 & 1 & 0.10 & 0.30 & 0 & 1 & 0.12 & 0.32 & 0 & 1 \\
\hline Wales & 0.05 & 0.22 & 0 & 1 & 0.04 & 0.21 & 0 & 1 & 0.06 & 0.23 & 0 & 1 \\
\hline No. of Workplaces & 1769 & & & & 785 & & & & 984 & & & \\
\hline
\end{tabular}


Table A2: Descriptive statistics on outcome and control variables, workplaces with MIXED respondents only

\begin{tabular}{|c|c|c|c|c|c|c|c|c|c|c|c|c|}
\hline & All & & & & Private & & & & Public & & & \\
\hline & Mean & St. Dev & Min & $\operatorname{Max}$ & Mean & St. Dev & Min & Max & Mean & St. Dev & Min & $\operatorname{Max}$ \\
\hline \multicolumn{13}{|l|}{ Outcomes } \\
\hline Workplace Av JS & 31.44 & 3.08 & 17.9 & 41.3 & 31.92 & 2.98 & 17.9 & 41.3 & 30.72 & 3.09 & 18.1 & 38.4 \\
\hline Workplace Av JS, disabled & 29.69 & 6.01 & 9 & 45 & 30.23 & 6.23 & 9 & 45 & 28.87 & 5.56 & 9 & 43 \\
\hline Workplace Av JS, nondisabled & 31.75 & 3.15 & 18.9 & 41 & 32.20 & 3.10 & 18.9 & 41 & 31.05 & 3.10 & 19.8 & 39.3 \\
\hline \multicolumn{13}{|l|}{ Controls } \\
\hline Has respondents with disabilities $(0 / 1)$ & 1.00 & 0.00 & 1 & 1 & 1.00 & 0.00 & 1 & 1 & 1.00 & 0.00 & 1 & 1 \\
\hline$\%$ respondents with Disability & 15.53 & 10.00 & 4.2 & 75 & 15.38 & 10.41 & 4.2 & 54.5 & 15.75 & 9.34 & 4.5 & 75 \\
\hline$\%$ on minimum wage & 4.27 & 14.12 & 0 & 100 & 6.17 & 16.96 & 0 & 100 & 1.36 & 7.13 & 0 & 100 \\
\hline Disability policies and practices & 2.98 & 1.74 & 0 & 7 & 2.43 & 1.52 & 0 & 7 & 3.82 & 1.72 & 0 & 7 \\
\hline Private establishment & 0.61 & 0.49 & 0 & 1 & 1.00 & 0.00 & 1 & 1 & 0.00 & 0.00 & 0 & 0 \\
\hline Single establishment & 0.23 & 0.42 & 0 & 1 & 0.30 & 0.46 & 0 & 1 & 0.11 & 0.32 & 0 & 1 \\
\hline Log workplace age & 3.25 & 1.06 & 0 & 6.6 & 3.08 & 1.04 & 0 & 6.6 & 3.51 & 1.04 & 0 & 5.9 \\
\hline Size5-9 & 0.04 & 0.20 & 0 & 1 & 0.06 & 0.24 & 0 & 1 & 0.01 & 0.10 & 0 & 1 \\
\hline Size10-24 & 0.11 & 0.31 & 0 & 1 & 0.15 & 0.35 & 0 & 1 & 0.05 & 0.23 & 0 & 1 \\
\hline size25-49 & 0.15 & 0.36 & 0 & 1 & 0.14 & 0.35 & 0 & 1 & 0.17 & 0.38 & 0 & 1 \\
\hline size $50-99$ & 0.20 & 0.40 & 0 & 1 & 0.19 & 0.39 & 0 & 1 & 0.21 & 0.41 & 0 & 1 \\
\hline Size100-199 & 0.15 & 0.36 & 0 & 1 & 0.16 & 0.36 & 0 & 1 & 0.14 & 0.35 & 0 & 1 \\
\hline Size200-499 & 0.15 & 0.36 & 0 & 1 & 0.15 & 0.36 & 0 & 1 & 0.15 & 0.36 & 0 & 1 \\
\hline Size500-999 & 0.08 & 0.28 & 0 & 1 & 0.09 & 0.29 & 0 & 1 & 0.07 & 0.26 & 0 & 1 \\
\hline Size1000-1999 & 0.05 & 0.23 & 0 & 1 & 0.03 & 0.18 & 0 & 1 & 0.09 & 0.28 & 0 & 1 \\
\hline Size2000+ & 0.06 & 0.24 & 0 & 1 & 0.03 & 0.18 & 0 & 1 & 0.10 & 0.30 & 0 & 1 \\
\hline Manufacturing & 0.10 & 0.30 & 0 & 1 & 0.16 & 0.37 & 0 & 1 & 0.01 & 0.07 & 0 & 1 \\
\hline Construction & 0.03 & 0.18 & 0 & 1 & 0.04 & 0.19 & 0 & 1 & 0.02 & 0.14 & 0 & 1 \\
\hline Whole sale \& retail trade & 0.08 & 0.26 & 0 & 1 & 0.12 & 0.33 & 0 & 1 & 0.00 & 0.00 & 0 & 0 \\
\hline Hotels, restaurants \& transport services & 0.11 & 0.31 & 0 & 1 & 0.13 & 0.33 & 0 & 1 & 0.08 & 0.26 & 0 & 1 \\
\hline Finance \& business services & 0.10 & 0.30 & 0 & 1 & 0.16 & 0.36 & 0 & 1 & 0.02 & 0.15 & 0 & 1 \\
\hline Public and community services & 0.23 & 0.42 & 0 & 1 & 0.16 & 0.36 & 0 & 1 & 0.35 & 0.48 & 0 & 1 \\
\hline Education & 0.16 & 0.36 & 0 & 1 & 0.07 & 0.26 & 0 & 1 & 0.29 & 0.46 & 0 & 1 \\
\hline Health & 0.19 & 0.40 & 0 & 1 & 0.17 & 0.38 & 0 & 1 & 0.23 & 0.42 & 0 & 1 \\
\hline North East & 0.04 & 0.20 & 0 & 1 & 0.04 & 0.19 & 0 & 1 & 0.05 & 0.22 & 0 & 1 \\
\hline North West & 0.15 & 0.35 & 0 & 1 & 0.14 & 0.35 & 0 & 1 & 0.16 & 0.37 & 0 & 1 \\
\hline Yorkshire \& the Humber & 0.08 & 0.27 & 0 & 1 & 0.08 & 0.27 & 0 & 1 & 0.08 & 0.27 & 0 & 1 \\
\hline
\end{tabular}




\begin{tabular}{lllllllllllll}
\hline East Midlands & 0.07 & 0.25 & 0 & 1 & 0.07 & 0.26 & 0 & 1 & 0.06 & 0.24 & 0 & 1 \\
West Midlands & 0.09 & 0.28 & 0 & 1 & 0.10 & 0.29 & 0 & 1 & 0.08 & 0.26 & 0 & 1 \\
East of England & 0.09 & 0.29 & 0 & 1 & 0.09 & 0.29 & 0 & 1 & 0.09 & 0.29 & 0 & 1 \\
London & 0.09 & 0.29 & 0 & 1 & 0.09 & 0.28 & 0 & 1 & 0.11 & 0.31 & 0 & 1 \\
South East & 0.13 & 0.34 & 0 & 1 & 0.15 & 0.36 & 0 & 1 & 0.10 & 0.30 & 0 & 1 \\
South West & 0.08 & 0.28 & 0 & 1 & 0.09 & 0.28 & 0 & 1 & 0.08 & 0.27 & 0 & 1 \\
Scotland & 0.12 & 0.32 & 0 & 1 & 0.12 & 0.32 & 0 & 1 & 0.12 & 0.32 & 0 & 1 \\
Wales & 0.05 & 0.23 & 0 & 1 & 0.04 & 0.20 & 0 & 1 & 0.08 & 0.26 & 0 & 1 \\
No. of Workplaces & 970 & & & & 587 & & & & & 383 & \\
\hline
\end{tabular}


Table A3: SUR estimates of workplace overall JS \& WD, workplace with mixed respondents only without controls

\begin{tabular}{|c|c|c|c|c|c|c|}
\hline & \multicolumn{2}{|c|}{ All } & \multicolumn{2}{|c|}{ Private } & \multicolumn{2}{|c|}{ Public } \\
\hline & $\begin{array}{l}\text { Respondents with } \\
\text { disabilities }\end{array}$ & $\begin{array}{l}\text { Respondents w/out } \\
\text { disabilities }\end{array}$ & $\begin{array}{l}\text { Respondents with } \\
\text { disabilities }\end{array}$ & $\begin{array}{l}\text { Respondents w/out } \\
\text { disabilities }\end{array}$ & $\begin{array}{l}\text { Respondents with } \\
\text { disabilities }\end{array}$ & $\begin{array}{l}\text { Respondents w/out } \\
\text { disabilities }\end{array}$ \\
\hline \multirow{2}{*}{ WD $(\%)$} & -0.026 & -0.007 & -0.076 & $-0.058 * * *$ & 0.018 & 0.032 \\
\hline & $(0.035)$ & $(0.019)$ & $(0.049)$ & $(0.022)$ & $(0.048)$ & $(0.021)$ \\
\hline \multirow[t]{2}{*}{ Constant } & $29.927 * * *$ & $31.296 * * *$ & $31.092 * * *$ & $32.294 * * *$ & $28.830 * * *$ & $30.410 * * *$ \\
\hline & $(0.657)$ & $(0.282)$ & $(0.812)$ & $(0.368)$ & (0.993) & $(0.327)$ \\
\hline No. of Workplaces & 970 & 970 & 587 & 587 & 383 & 383 \\
\hline
\end{tabular}

Robust standard errors in parentheses

Estimates use WERS2011 establishment survey weights.

$* * * \mathrm{p}<0.01, * * \mathrm{p}<0.05, * \mathrm{p}<0.1$ 
Table A4: SUR estimates of workplace overall JS \& WD, workplaces with mixed respondents with workplace controls

\begin{tabular}{|c|c|c|c|c|c|c|}
\hline & \multicolumn{2}{|c|}{ All } & \multicolumn{2}{|c|}{ Private } & \multicolumn{2}{|c|}{ Public } \\
\hline & $\begin{array}{l}\text { Respondents with } \\
\text { disabilities }\end{array}$ & $\begin{array}{l}\text { Respondents w/out } \\
\text { disabilities }\end{array}$ & $\begin{array}{l}\text { Respondents with } \\
\text { disabilities }\end{array}$ & $\begin{array}{l}\text { Respondents w/out } \\
\text { disabilities }\end{array}$ & $\begin{array}{l}\text { Respondents with } \\
\text { disabilities }\end{array}$ & $\begin{array}{l}\text { Respondents w/out } \\
\text { disabilities }\end{array}$ \\
\hline \multirow[t]{2}{*}{ WD $(\%)$} & -0.014 & -0.009 & -0.051 & $-0.052 * * *$ & 0.011 & 0.020 \\
\hline & $(0.038)$ & $(0.016)$ & $(0.049)$ & $(0.019)$ & $(0.051)$ & $(0.017)$ \\
\hline \multirow[t]{2}{*}{ Employees on Minimum Wage (\%) } & $0.038 * *$ & -0.006 & $0.051 * * *$ & -0.004 & 0.016 & -0.010 \\
\hline & $(0.017)$ & $(0.009)$ & $(0.015)$ & $(0.012)$ & $(0.044)$ & $(0.018)$ \\
\hline \multirow{2}{*}{ Log workplace age } & $-1.146^{* * *}$ & 0.126 & $-1.402 * * *$ & 0.046 & $-1.145^{*}$ & 0.139 \\
\hline & $(0.351)$ & $(0.102)$ & $(0.307)$ & $(0.142)$ & $(0.595)$ & $(0.150)$ \\
\hline \multirow[t]{2}{*}{ Single establishment } & -0.185 & -0.200 & -0.157 & 0.626 & 0.025 & -0.428 \\
\hline & $(0.844)$ & $(0.330)$ & (1.305) & $(0.480)$ & (1.131) & $(0.423)$ \\
\hline \multirow[t]{2}{*}{ Private establishment } & $2.307 * * *$ & $1.637 * * *$ & & & & \\
\hline & $(0.800)$ & $(0.312)$ & & & & \\
\hline \multicolumn{7}{|l|}{ Workplace size (base 5 to 9 employees) } \\
\hline \multirow[t]{2}{*}{ 10-24 employees } & -0.418 & $-1.904 * *$ & -1.971 & $-2.524 * * *$ & 1.717 & -1.333 \\
\hline & $(1.701)$ & $(0.901)$ & (2.198) & $(0.955)$ & $(3.721)$ & $(2.405)$ \\
\hline \multirow[t]{2}{*}{ 25-49 employees } & -1.961 & $-3.154 * *$ & $-4.332 * *$ & $-4.852 * * *$ & 0.655 & -0.903 \\
\hline & $(1.724)$ & $(1.307)$ & $(2.190)$ & $(1.560)$ & $(3.508)$ & $(2.225)$ \\
\hline \multirow[t]{2}{*}{ 50-99 employees } & -2.313 & $-2.624 * * *$ & -3.006 & $-3.672 * * *$ & -2.619 & -1.388 \\
\hline & $(1.741)$ & $(0.884)$ & $(2.116)$ & $(0.916)$ & $(3.732)$ & $(2.277)$ \\
\hline \multirow[t]{2}{*}{ 100-199 employees } & -1.354 & $-2.535 * * *$ & -1.771 & $-3.103 * * *$ & -2.116 & -2.638 \\
\hline & (1.666) & $(0.853)$ & (2.227) & $(0.899)$ & (3.567) & (2.229) \\
\hline \multirow[t]{2}{*}{ 200-499 employees } & -1.409 & $-2.981 * * *$ & -2.255 & $-2.956 * * *$ & -0.844 & -2.848 \\
\hline & (1.679) & $(0.840)$ & $(2.185)$ & $(0.906)$ & $(3.563)$ & $(2.235)$ \\
\hline \multirow[t]{2}{*}{ 500-999 employees } & -2.613 & $-2.692 * * *$ & -2.680 & $-3.135 * * *$ & -3.599 & -1.984 \\
\hline & $(1.656)$ & $(0.866)$ & $(2.131)$ & $(0.895)$ & $(3.504)$ & $(2.279)$ \\
\hline \multirow[t]{2}{*}{ 1000-1999 employees } & -1.438 & $-3.657 * * *$ & -3.580 & $-3.906 * * *$ & -0.906 & -2.549 \\
\hline & $(1.947)$ & $(0.865)$ & $(2.886)$ & $(1.025)$ & $(3.609)$ & $(2.225)$ \\
\hline \multirow{2}{*}{ 2000+ employees } & 1.464 & $-2.492 * * *$ & -0.632 & $-3.886 * * *$ & 2.244 & -0.864 \\
\hline & $(1.793)$ & $(0.890)$ & $(2.657)$ & $(1.077)$ & $(3.632)$ & $(2.240)$ \\
\hline \multicolumn{7}{|l|}{ Industry (base manufacturing) } \\
\hline \multirow[t]{2}{*}{ Construction } & -0.801 & -0.191 & -3.621 & -0.279 & -2.269 & $-5.837 * * *$ \\
\hline & $(2.352)$ & $(0.976)$ & $(3.151)$ & $(1.367)$ & $(4.233)$ & $(2.040)$ \\
\hline \multirow{2}{*}{ Whole sale \& retail trade } & 0.628 & $1.372 * *$ & -0.772 & 0.985 & & \\
\hline & $(1.573)$ & $(0.657)$ & $(1.686)$ & $(0.680)$ & & \\
\hline \multirow[t]{2}{*}{ Hotels, restaurants \& transport services } & -1.803 & -0.846 & -1.617 & -0.988 & -6.434 & $-6.524 * * *$ \\
\hline & $(1.622)$ & $(0.676)$ & $(1.644)$ & $(0.650)$ & $(4.526)$ & $(1.783)$ \\
\hline
\end{tabular}




\begin{tabular}{|c|c|c|c|c|c|c|}
\hline \multirow[t]{2}{*}{ Finance $\&$ business services } & -1.261 & $1.983 * * *$ & -2.495 & $1.265 * *$ & -1.160 & -2.721 \\
\hline & (1.519) & $(0.541)$ & (1.560) & $(0.595)$ & (4.170) & (1.843) \\
\hline \multirow[t]{2}{*}{ Public and community services } & -0.118 & $1.195 * *$ & -0.818 & $1.438 * * *$ & -2.915 & $-5.417 * * *$ \\
\hline & $(1.221)$ & $(0.494)$ & $(1.269)$ & $(0.436)$ & $(3.960)$ & $(1.746)$ \\
\hline \multirow[t]{2}{*}{ Education } & 0.871 & $2.304 * * *$ & 1.028 & 0.698 & -2.484 & $-2.997^{*}$ \\
\hline & (1.374) & $(0.584)$ & $(1.795)$ & $(0.673)$ & $(4.057)$ & $(1.754)$ \\
\hline \multirow[t]{2}{*}{ Health } & 1.179 & $2.510 * * *$ & 0.265 & $2.080 * * *$ & -1.971 & $-4.117 * *$ \\
\hline & $(1.288)$ & $(0.567)$ & $(1.430)$ & $(0.536)$ & $(3.798)$ & $(1.735)$ \\
\hline \multicolumn{7}{|c|}{ Region (base, North East) } \\
\hline \multirow[t]{2}{*}{ North West } & $-2.356 * *$ & -0.067 & $-2.517^{*}$ & -0.133 & -2.687 & -0.186 \\
\hline & (1.166) & $(0.576)$ & (1.317) & $(0.591)$ & (1.713) & $(0.753)$ \\
\hline \multirow[t]{2}{*}{ Yorkshire \& the Humber } & $-2.300^{*}$ & 0.372 & -1.836 & 0.803 & $-3.223 * *$ & -0.662 \\
\hline & $(1.236)$ & $(0.654)$ & $(1.625)$ & $(0.779)$ & $(1.466)$ & $(0.809)$ \\
\hline \multirow[t]{2}{*}{ East Midlands } & $-3.686 * *$ & $1.302 * *$ & $-4.363 * * *$ & $1.528^{*}$ & -3.404 & 1.253 \\
\hline & (1.470) & $(0.652)$ & $(1.546)$ & $(0.815)$ & $(2.469)$ & $(0.779)$ \\
\hline \multirow[t]{2}{*}{ West Midlands } & $-5.052 * * *$ & -0.569 & $-7.573 * * *$ & $-1.316 * *$ & -2.046 & -0.527 \\
\hline & $(1.281)$ & $(0.604)$ & $(1.352)$ & $(0.650)$ & (1.420) & $(0.765)$ \\
\hline \multirow[t]{2}{*}{ East of England } & $-3.155^{* * *}$ & 0.590 & $-4.460 * * *$ & 0.724 & $-3.010 * *$ & 0.043 \\
\hline & (1.047) & $(0.578)$ & (1.609) & $(0.704)$ & (1.384) & $(0.714)$ \\
\hline \multirow[t]{2}{*}{ London } & -1.684 & -0.396 & -1.113 & -0.227 & -2.150 & -0.219 \\
\hline & $(1.829)$ & $(0.607)$ & (1.614) & $(0.837)$ & $(2.439)$ & $(0.763)$ \\
\hline \multirow[t]{2}{*}{ South East } & -0.793 & -0.631 & -0.127 & $-1.537 * *$ & -1.673 & 0.210 \\
\hline & $(1.327)$ & $(0.634)$ & (1.641) & $(0.691)$ & (1.869) & $(0.722)$ \\
\hline \multirow[t]{2}{*}{ South West } & $-1.868^{*}$ & -0.041 & 0.616 & 0.298 & $-3.263 * *$ & -0.587 \\
\hline & (1.126) & $(0.682)$ & (1.403) & $(0.914)$ & $(1.430)$ & $(0.866)$ \\
\hline \multirow[t]{2}{*}{ Scotland } & $-2.352 * *$ & -0.112 & $-2.493 * *$ & -0.146 & -2.521 & -0.088 \\
\hline & (1.028) & $(0.593)$ & $(1.201)$ & $(0.549)$ & (1.547) & $(0.814)$ \\
\hline \multirow{2}{*}{ Wales } & -0.135 & 0.337 & -2.481 & 0.809 & 0.671 & 0.063 \\
\hline & $(1.401)$ & $(0.603)$ & $(2.082)$ & $(0.600)$ & (1.790) & $(0.773)$ \\
\hline \multirow[t]{2}{*}{ Constant } & $35.425 * * *$ & $31.601 * * *$ & $40.778 * * *$ & $34.786 * * *$ & $37.803 * * *$ & $36.557 * * *$ \\
\hline & $(2.887)$ & $(1.265)$ & $(3.302)$ & $(1.325)$ & $(5.787)$ & $(2.989)$ \\
\hline No. of Workplaces & 970 & 970 & 587 & 587 & 383 & 383 \\
\hline
\end{tabular}

Robust standard errors in parentheses

Estimates use WERS2011 establishment survey weights. There are no public sector workplaces in the wholesale and retail industry.

$* * * \mathrm{p}<0.01, * * \mathrm{p}<0.05, * \mathrm{p}<0.1$ 